\title{
Metode Weighted Product Untuk Pendukung Keputusan Penilaian Pencemaran Udara Berdasarkan Limbah Gas dan Kualitas Udara Ambien
}

\author{
http://dx.doi.org/10.28932/jutisi.v5i1.919
}

\author{
Wiedya Putri Hartarani ${ }^{\# 1}$, Wildan Mahmud ${ }^{* 2}$, Ery Mintorini ${ }^{\# 3}$ \\ "Program Studi Sistem Informasi, STMIK KADIRI \\ Jl. Balowerti 2 No. 26-30 Kediri 64121 \\ ${ }^{1}$ wiedya.hartarini@gmail.com \\ ${ }^{3}$ ery mintolyahoo.co.id \\ *Program Studi Sistem Informasi, STMIK KADIRI \\ Jl. Balowerti 2 No. 26-30 Kediri 64121 \\ ${ }^{2}$ wildan.mahmudegmail. com
}

\begin{abstract}
This study aims to determine the level of air pollution based on gas waste and ambient air quality, so it can be known which chimney releases waste gas the most and the least. It also knows which villages are most affected and safest from gas waste from PG Mojopanggung. Weighted Product method is used to calculate the level of air pollution. The results showed that from the side of the gas waste, the Stork I Boiler Chimney is the most discharging chimney gas waste, while the value of pollution by chimney kettle in PG Mojopanggung all does not exceed the standard quality that has been determined. Conversely, in terms of ambient air quality, Jatimulyo village is the village most affected by gas waste from PG Mojopanggung. There are some air pollutants that exceed the specified quality standard but not too much difference. To overcome the air pollutant that exceeds the quality standard, PG Mojopanggung performs the gas waste treatment and several other solutions.
\end{abstract}

Keywords - Air Pollution, Ambient Air Quality, Decision Support System, Gas Waste, Weighted Product.

\section{Pendahuluan}

Gula memegang peranan penting dalam ekonomi pangan Indonesia. Keberadaan gula sebagai salah satu dari sembilan bahan pokok masyarakat sekarang cenderung meningkat, menjadikan perusahaan dan pabrik gula memiliki posisi strategi dalam transformasi ekonomi. Hal ini dapat dibuktikan dengan Indonesia pernah memegang kejayaan industri gula pada tahun 1930-an dengan prestasi tertinggi sebagai tenaga pengekspor gula tertinggi sebanyak 2,4 juta ton [1]. Berdasarkan catatan Kementerian Perdagangan, konsumsi gula dalam negeri berkisar antara 3,2 juta - 3,5 juta ton per tahun, dengan asumsi minimum 250.000 per bulan [2]. Akibat sampingan dari perkembangan industrialisasi gula ini berupa limbah industri, baik diproduksi secara langsung maupun tidak langsung. Limbah industrial ini yang nantinya akan dapat memberikan dampak negatif bagi semua komponen baik perusahaan maupun masyarakat.

Pabrik Gula (PG) Mojopanggung menghasilkan limbah yang harus dikeluarkan ke lingkungan. Limbah ini dapat mengakibatkan keseimbangan lingkungan terganggu sehingga kualitas lingkungan semakin merosot dan daya dukung lingkungan semakin rendah. Limbah yang dihasilkan tersebut berupa limbah padat, cair dan gas. Limbah gas dikeluarkan melalui cerobong ketel dan gas buang cerobong sulfitir, meskipun limbah gas dari cerobong sulfitir tidak dapat dikontrol karena sifatnya yang insidental. Dari ketiga jenis limbah yang dikeluarkan PG Mojopanggung, limbah gas adalah limbah yang paling berbahaya jika melebihi ambang baku mutu yang diperbolehkan. Sebuah pengkajian di tahun 2013 oleh Badan Internasional WHO untuk Penelitian Kanker menyimpulkan bahwa polusi udara luar ruangan merupakan karsinogen atau penyebab kanker bagi manusia terutama untuk kanker paru-paru [3].

Sebelum melakukan pengelolahan limbah, PG Mojopanggung memerlukan bantuan media pengontrol untuk mengetahui apakah limbah gas yang mereka keluarkan dari cerobong mereka tergolong limbah yang masih aman atau limbah yang membahayakan dan mengetahui cerobong mana yang paling aman dan paling tidak aman limbahnya. Selain untuk mengetahui tingkat bahaya limbah gas dari cerobong dan mengetahui cerobong mana yang paling tidak aman limbahnya, PG Mojopanggung juga memerlukan media untuk mengetahui kawasan mana yang paling parah terkena dampak dari 
limbah gas yang mereka keluarkan dilihat dari kualitas udara ambiennya.

Untuk bisa melakukan hal tersebut diatas, sistem pendukung keputusan diperlukan sebagai media pengontrol untuk mengetahui kondisi limbah gas dari cerobong dan kualitas udara ambien di lingkungan sekitar pabrik serta untuk mengetahui mana cerobong yang mengeluarkan limbah paling banyak dan desa mana yang paling tercemar. Penggunaan metode Weighted Product dipilih dalam penelitian ini karena metode ini dapat menunjukkan hanya nilai terbesar dari cerobong ketel dengan pengeluaran limbah paling berbahaya dan lingkungan di sekitar pabrik yang paling buruk kualitas udara ambiennya.

Ruang lingkup penelitian ini adalah sebagai berikut :

1. nilai yang digunakan sebagi pencemar udara ini adalah limbah gas dari cerobong ketel dan kualitas udara ambien di lingkungan PG Mojopanggung.

2. kriteria - kriteria dalam menilai pencemaran udara adalah Peraturan Gubernur Jawa Timur (Pergub Jatim) Nomor 10 Tahun 2009 [4].

3. cerobong ketel dan desa di sekitar Pabrik Gula Mojopanggung digunakan sebagai alternatif, sedangkan cerobong sulfitit tidak dimasukkan sebagai alternatif karena sulfitir hanya akan mengeluarkan limbah gas secara insidental ketika aliran nira terjadi fluktuasi saja

Tujuan penelitian ini adalah mengetahui cerobong mana yang mengeluarkan limbah gas paling banyak dan paling sedikit dan mengetahui desa yang paling terdampak dan paling aman dari limbah gas PG Mojopanggung.

\section{LANDASAN TEORI}

\section{A. Sistem Pendukung Keputusan}

Sistem Pendukung Keputusan terdiri dari tiga komponen utama. Komponen - komponen tersebut adalah sebagai berikut [5] :

1. Subsistem Data (Database), yaitu komponen Sistem Pendukung Keputusan yang berguna sebagai penyedia data bagi sistem

2. Subsistem Model (Model Base), yaitu suatu tiruan dari alam nyata

3. Subsistem Dialog (User System Interface), yaitu fasilitas yang mampu mengintegrasikan sistem yang terpasang dengan pengguna secara interaktif

Hubungan komponen - komponen sistem pendukung keputusan dapat dilihat pada gambar 1 [5].

\section{B. Weighted Product}

Weighted Product merupakan suatu metode di dalam penentuan sebuah keputusan dengan cara perkalian untuk menghubungkan rating attribute, dimana rating setiap atribut dipangkatkan dulu dengan bobot atribut yang bersangkutan [6]. Metode ini merupakan salah satu metode yang digunakan dalam menyelesaikan masalah Multi Attribute Decision Making (MADM) untuk mencari alternatif paling optimal dengan kriteria tertentu [7].

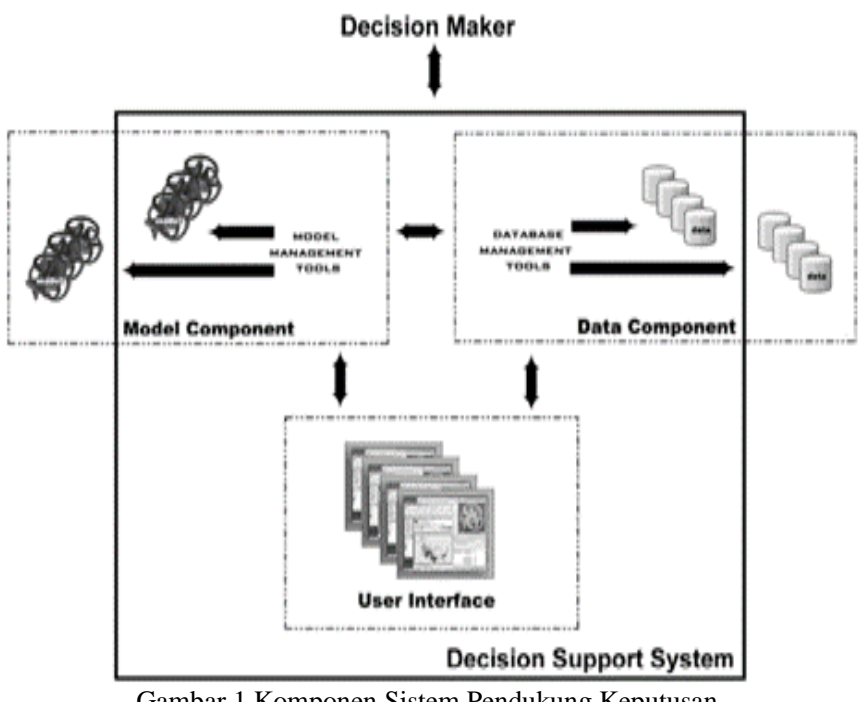

Gambar 1 Komponen Sistem Pendukung Keputusan

Langkah - langkah yang dilakukan dalam penyelesaian masalah menggunakan metode Weighted Product adalah [6] :

1. Normalisasi Atau Perbaikan Bobot (Wj )

Melakukan normalisasi atau perbaikan bobot untuk menghasilkan $\sum \mathrm{Wj}=1$ menggunakan persamaan :

$$
W_{j}=\frac{W_{j}}{\sum W_{j}}
$$

dimana $\mathrm{j}=1,2, \ldots \mathrm{m}$ adalah banyak kriteria

\section{Menentukan Nilai Vektor (S)}

$S_{i}=\pi_{j-1}^{n} x_{i j} W_{j} \pi_{j-1}^{n} W_{j}$

dimana $i=1,2, \ldots, n$ adalah banyak alternatif

Menentukan nilai vektor (S) dengan mengalikan cara seluruh kriteria dengan alternatif hasil normalisasi atau perbaikan bobot yang bernilai positif untuk kriteria keuntungan (benefit) dan berpangkat negatif untuk kriteria biasa (cost). (S) merupakan preferensi kriteria. (n) merupakan banyaknya kriteria dan (x) adalah nilai kriteria.

3. Menentukan Nilai Vektor (V)

$$
V_{i}=\frac{\pi_{j=1}^{n} x_{i j} W_{j}}{\pi_{j-1}^{n}\left(x_{j}^{w}\right) W_{j}}
$$

Menentukan nilai vektor (V) dimana (V) merupakan preferensi alternative yang akan digunakan untuk perankingan dari masing -masing jumlah nilai vektor (S) dengan jumlah seluruh nilai vektor (S) 


\section{Gula}

Gula merupakan salah bahan pokok yang diperlukan seluruh umat manusia sehari-hari [8]. Berdasarkan catatan Kementerian Perdagangan, konsumsi gula dalam negeri berkisar antara 3,2 juta - 3,5 juta ton per tahun, dengan asumsi minimum 250.000 per bulan [2]. Dalam pembuatan gula diperlukan bahan baku dan bahan pembantu berikut [9] :

\section{Bahan Baku}

Tebu merupakan bahan baku dalam proses pembuatan gula yang diproses berasal dari petani

2. Bahan Bantuan

a. Kapur Tohor $(\mathrm{CaO})$, digunakan pada proses pemurnian sulfitrasi alkalis.Tujuan dari pencampuran susu kapur dengan nira agar terjadi reaksi penetralan antara ion - ion pospat yang ada di dalam nira dengan $\mathrm{Ca}^{2+}$ dalam kapur susu membentuk endapan $\mathrm{Ca}_{3}\left(\mathrm{PO}_{4}\right)_{2}$.

b. Belerang, untuk membuat gas $\mathrm{SO}_{2}$ yang digunakan dalam proses pemurnian nira (sulfitrasi) sehingga terbentuk endapan $\mathrm{CaSO}_{3}$ yang tidak mudah pecah.

c. Air, digunakan untuk membantu proses ekstrasi nira yang terkandung dalam tebu pada proses penggilingan.

d. Floculant, untuk mempercepat pembentukan floc (kotoran) hingga kotoran mudah mengendap

Aliran proses pembuatan gula pasir di pabrik gula secara umum dapat dilihat pada gambar 2 [9]

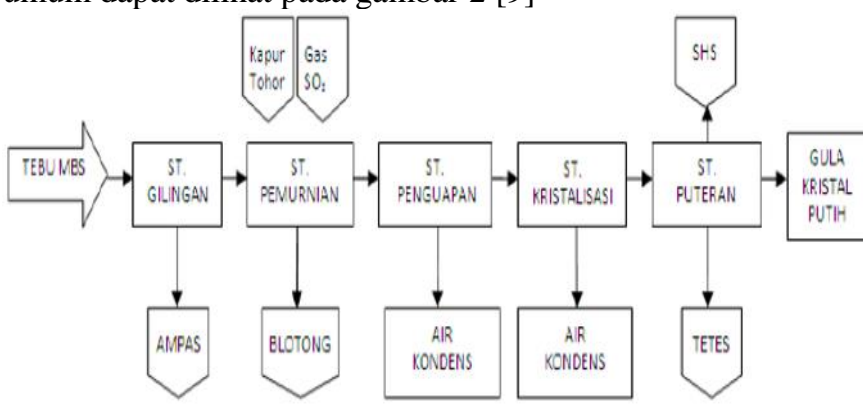

Gambar 2 Flowchart Proses Pembuatan Gula

Dari gambar diagram alir proses pembuatan gula diatas, proses pembuatan gula di pabrik gula secara garis berasnya dapat di uraikan sebagai berikut [9] :

1. Timbangan untuk menimbang tebu sebelum masuk penggilingan

2. Stasiun Gilingan untuk memisahkan ampas tebu (bagase) dan nira (juice) dalam batang tebu.

3. Stasiun Pemurnian untuk memisahkan bukan gula dari cairan nira sehingga diperoleh nira yang jernih dan akan dihasilkan kristal yang baik

4. Stasiun Penguapan untuk menghilangkan sejumlah air yang terkandung dalam nila jernih sehingga diperoleh cairan nira kental dengan konsentrasi tertentu dan siap diproses pada stasiun masakan
5. Stasiun Masakan (stasiun kristalisasi) untuk merubah sukrosa dari cairan nira kental menjadi kristal - kristal gula yang seragam sesuai dengan ukuran yang diinginkan.

6. Stasiun Puteran untuk memisahkan kristal gula dari larutannya agar didapatkan gula sebanyak - banyaknya.

7. Stasiun Penyelesaian, bertujuan untuk menyelesaikan proses sampai penyimpanan produk gula dalam gudang

Dari setiap proses pembuatan gula tentunya pabrik gula akan menghasilkan hasil sampingan berupa limbah. Limbah dari pabrik gula berdasarkan bentuknya dibagi menjadi 3, yaitu [10] pertama limbah padat berupa ampas tebu, blotong dan abu pembakaran ampas tebu, kedua limbah cair terdiri dari air bekas kondensor dan air cucian tapisan dan ketiga, limbah gas, umumnya adalah asap cerobong yang merupakan gas sisa pembakaran dari ketel uap.

\section{Pencemaran Udara}

Pencemaran Udara adalah peristiwa pemasukan dan/atau penambahan senyawa, bahan dan energi ke dalam lingkungan udara akibat adanya kegiatan alam dan manusia sehingga temperatur dan karakteristik udara tidak sesuai lagi untuk tujuan pemanfaatannya yang paling baik atau dengan singkat dapat dikatakan bahwa nilai lingkungan udara tersebut telah menurun. Pencemaran udara diklasifikasikan menjadi 2 kategori menurut cara pencermaran masuk atau dimasukkan ke atmosfer yaitu [11] pertama pencemaran primer, cemaran yang diemisikan secara langsung dari sumber cemaran, dan kedua pencemaran sekunder, cemaran yang terbentuk oleh proses kimia di atmosfer.

Sumber pencemaran dari aktifitas manusia (antropogenik) adalah setiap kegiatan manusia yang mengemisikan cemaran primer ke atmosfer. Ada 2 (dua) kategori antropogenik, yaitu [11] pertama, sumber tetap seperti pembangkit energi listrik dengan bakar fosil, pabrik, rumah tangga, jasa dan lain - lain, dan kedua sumber bergerak, seperti truk, bus, pesawat terbang, dan kereta api.

Pencemaran udara dapat menimbulkan gangguan kesehatan pada manusia dengan berbagai cara. WHO Inter Regional Sysposium on Criteria for Air Quality and Method of Measurement telah menetapkan beberapa tingkat konstentrasi pencemaran udara dalam hubungan dengan akibatnya terhadap kesehatan/ lingkungan sebagai berikut [11] : tingkat 1, konsentrasi dan waktu expose dimana tidak ditemukan akibat apa - apa, baik secara langsung maupun tidak langsung, tingkat 2, konsentrasi dimana mungkin ditemui iritasi pada panca indera, tingkat 3 konsentrasi dimana mungkin timbul hambatan pada fungsi-fungsi faali yang vital serta perubahan yang mungkin dapat menimbulkan penyakit menahun atau pemendekan umur, dan tingkat 4 , konsentrasi dimana mungkin terjadi penyakit akut atau kematian. 


\section{E. Kualitas Udara Ambien}

Kualitas udara ambien merupakan tahap awal untuk memahami dampak negatif pencemaran terhadap lingkungan. Kualitas udara ambien ditentukan oleh kuantitas emisi cemaran dari sumber cemaran, dan proses transportasi, konversi dan penghilangan cemaran di atmosfer [11].

Terdapat dua jenis baku mutu pada kualitas udara ambien, Baku mutu tersebut adalah sebagai berikut pertama, baku mutu primer, ditetapkan untuk melindungi pada batas keamanan yang mencukupi (adequate margin safety) kesehatan masyarakat dimana secara umum ditetapkan untuk melindungi sebagian masyarakat (15\% - 20\%) yang rentan terhadap pencemaran udara, dan kedua baku mutu sekunder, ditetapkan untuk melindungi kesejahteraan masyarakat dari setiap efek negatif pencemaran udara yang telah diketahui atau yang dapat diantisipasi [11]. Tabel I merupakan tabel baku mutu kualitas udara ambien berdasarkan Pergub Jatim No. 10 Tahun 2009.

TABEL I

Nilai BaKU Mutu Kualitas Udara Ambien

\begin{tabular}{|c|l|l|r|l|}
\hline No & \multicolumn{1}{|c|}{ Parameter } & \multicolumn{1}{|c|}{ Satuan } & $\begin{array}{r}\text { Baku } \\
\text { Mutu }\end{array}$ & \multicolumn{1}{|c|}{ Metode } \\
\hline 1 & Sulfur Dioksida $\left(\mathrm{SO}_{2}\right)$ & $\mathrm{ppm}$ & 0,1 & Pararosanilin \\
\hline 2 & $\begin{array}{l}\text { Karbon Monoksida } \\
(\mathrm{CO})\end{array}$ & $\mathrm{ppm}$ & 20 & NDIR \\
\hline 3 & $\begin{array}{l}\text { Oksida Nitrogen } \\
\left(\mathrm{NO}_{\mathrm{x}}\right)\end{array}$ & $\mathrm{ppm}$ & 0,05 & Salzman \\
\hline 4 & Debu & $\mathrm{mg} / \mathrm{nm}^{3}$ & 0,26 & Gravimetrik \\
\hline 5 & Timah Hitam $(\mathrm{Pb})$ & $\mathrm{mg} / \mathrm{nm}^{3}$ & 0,06 & Gravimetrik \\
\hline 6 & Hidrogen $\mathrm{Sulfida}\left(\mathrm{H}_{2} \mathrm{~S}\right)$ & $\mathrm{ppm}$ & 0,03 & Metylen Blue \\
\hline 7 & Amonia $\left(\mathrm{NH}_{3}\right)$ & $\mathrm{ppm}$ & 2 & Indophenol \\
\hline
\end{tabular}

Sumber : Pergub Jatim No.10 Tahun 2009

\section{F. Limbah Gas}

Limbah gas adalah limbah yang memanfaatkan udara sebagai media. Limbah gas yang dihasilkan berlebihan dapat mencemari udara serta dapat mengganggu kesehatan masyarakat [12]. Penambahan gas ke dalam udara melampaui kandungan alami akibat kegiatan manusia akan menurunkan kualitas udara [11]. Salah satu sumber limbah gas adalah emisi gas buang dari cerobong ketel. Tabel II merupakan tabel baku mutu limbah gas yang berasal dari cerobong ketel dengan menggunakan bahan bakar biomassa berdasarkan Pergub Jatim No. 10 Tahun 2009.

TABEL II

Nilai Baku Mutu Limbah Gas Dari Cerobong Ketel DENGAN BAHAN BAKAR BIOMASSA

\begin{tabular}{|c|l|c|r|}
\hline No & \multicolumn{1}{|c|}{ Parameter } & Satuan & Baku Mutu \\
\hline 1 & Partikuler & $\mathrm{mg} / \mathrm{nm}^{3}$ & 250 \\
\hline 2 & Sulfur Dioksida $\left(\mathrm{SO}_{2}\right)$ & $\mathrm{mg} / \mathrm{nm}^{3}$ & 600 \\
\hline 3 & Nitrogen Dioksida $\left(\mathrm{NO}_{2}\right)$ & $\mathrm{mg} / \mathrm{nm}^{3}$ & 800 \\
\hline 4 & Opasitas & $\%$ & 30 \\
\hline
\end{tabular}

\section{METODE PENELITIAN}

Ada empat tahap yang dilakukan untuk pengembangan sistem pendukung keputusan penilaian pencemaran udara di PG Mojopanggung meliputi tahap pengumpulan data, analisis sistem, desain sistem, dan implementasi sistem. Tahap pengumpulan data berupa data primer berupa hasil wawancara dengan Manager Quality Assurance PG Mojopanggung, dan data sekunder berupa laporan-laporan yang berkaitan erat dengan limbah gas dan kualitas udara. Tahap analisis sistem yang memetakan sistem ke dalam fungsi-fungsi utama yang ada dalam sistem dalam bentuk activity diagram dan use case diagram. Tahap desain sistem berupa aktivitas untuk mendesain database, user interface berupa form, report, dan menu. Tahap implementasi sistem yang menerapkan hasil analisis dan desain sistem tersebut ke dalam bahasa pemrograman berbasis web.

\section{A. Flowchart Weighted Product}

Gambar 3 menunjukkan bagan alir sistem pendukung keputusan dengan metode Weighted Product yang dimulai dengan memasukkan data kriteria berupa nama kriteria, atribut dan bobot. Kemudian dilanjutkan dengan menghitung bobot kriteria. Selanjutnya yang dilakukan adalah memasukkan data alternatif. Data kriteria dan data alternatif kemudian direlasikan melalui penilaian sekaligus memasukkan nilai penilaian untuk masing - masing alternatif dan kriteria. Setelah memasukkan nilai penilaian lalu menghitung vektor $\mathrm{S}$ dan terakhir menghitung vektor $\mathrm{V}$.

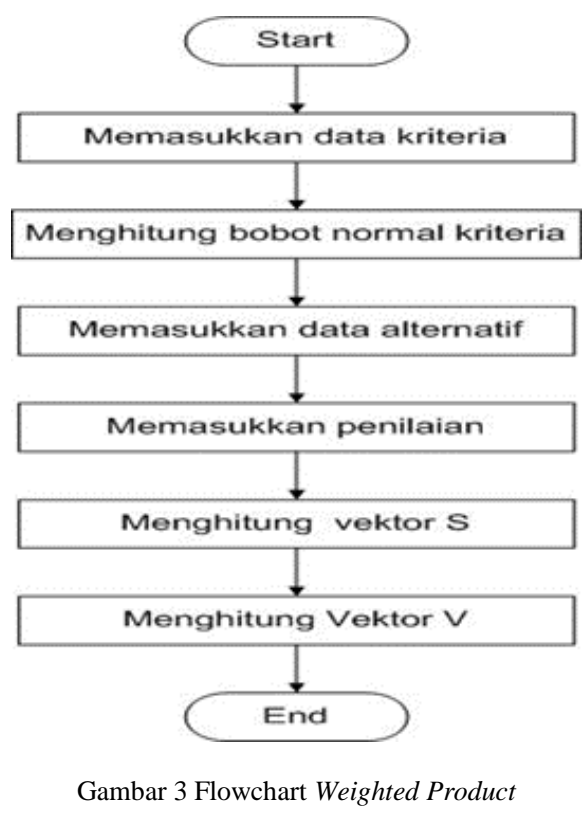




\section{HASIL DAN PEMBAHASAN}

\section{A. Analisis dan Perhitungan Weighted Product}

Analisis kriteria digunakan untuk menggambarkan apa saja yang menjadi bahan untuk proses penilaian pencemaran udara oleh limbah gas dari pabrik gula. Dalam analisis kriteria ini akan menjelaskan atribut dan bobot dari masingmasing kriteria tergantung pada tingkat bahayanya bagi manusia.

Kriteria yang ditentukan untuk penilaian limbah gas dari cerobong ketel dan kualitas udara ambien desa di sekitar pabrik dapat dilihat pada tabel III dan tabel IV.

TABEL III

TABel Data Kriteria Limbah Gas CeROBOng KeTEL

\begin{tabular}{|c|l|c|c|}
\hline No & \multicolumn{1}{|c|}{ Nama Kriteria } & Atribut & Bobot \\
\hline 1 & Nitrogen Dioksida & Benefit & 5 \\
\hline 2 & Sulfur Dioksida & Benefit & 5 \\
\hline 3 & Partkel & Benefit & 5 \\
\hline 4 & Opasitas & Benefit & 5 \\
\hline
\end{tabular}

TABEL IV

TABel Data Kualitas Udara AMBIEn Desa Di SEKITAR PABRIK GUlA

\begin{tabular}{|c|l|c|c|}
\hline No & \multicolumn{1}{|c|}{ Nama Kriteria } & Atribut & Bobot \\
\hline 1 & Nitrogen Dioksida & Benefit & 5 \\
\hline 2 & Oksida Nitrogen & Benefit & 5 \\
\hline 3 & Sulfur Dioksida & Benefit & 5 \\
\hline 4 & Hidrogen Sulfida & Benefit & 5 \\
\hline 5 & Amonia & Benefit & 5 \\
\hline 6 & Debu & Benefit & 5 \\
\hline 7 & Timah Hitam & Benefit & 5 \\
\hline
\end{tabular}

Bobot dari masing - masing kriteria tersebut kemudian dilakukan normalisasi pada tabel $\mathrm{V}$.

TABEL V

TABEl DATA KRITERIA Limbah GAS CEROBONG KETEL TERNORMALISASI

\begin{tabular}{|c|l|c|c|c|}
\hline No & Nama Kriteria & Bobot & Hitungan & Bobot Normal \\
\hline 1 & Nitrogen Dioksida & 5 & $5 /(5+5+5+5)$ & 0.25 \\
\hline 2 & Sulfur Dioksida & 5 & $5 /(5+5+5+5)$ & 0.25 \\
\hline 3 & Partikel & 5 & $5 /(5+5+5+5)$ & 0.25 \\
\hline 4 & Opasitas & 5 & $5 /(5+5+5+5)$ & 0.25 \\
\hline
\end{tabular}

Bobot normal diperoleh dari bobot alternatif dibagi total bobot alternatif. Bobot normal dari cerobong ketel juga memiliki nilai positif karena atribut dari masing - masing kriteria bersifat benefit dapat dilihat pada tabel VI.

TABEL VI

TABel Data Kualitas UdARa AMbIEn Desa Di SEKITAR PABriK GULA TERNORMALISASI

\begin{tabular}{|c|l|c|c|c|}
\hline No & Nama Kriteria & Bobot & Hitungan & $\begin{array}{c}\text { Bobot } \\
\text { Normal }\end{array}$ \\
\hline 1 & Nitrogen Dioksida & 5 & $5 /(5+5+5+5+5+5+5)$ & 0.14285714 \\
\hline 2 & Oksida Nitrogen & 5 & $5 /(5+5+5+5+5+5+5)$ & 0.14285714 \\
\hline 3 & Sulfur Dioksida & 5 & $5 /(5+5+5+5+5+5+5)$ & 0.14285714 \\
\hline 4 & Hidrogen Sulfida & 5 & $5 /(5+5+5+5+5+5+5)$ & 0.14285714 \\
\hline
\end{tabular}

\begin{tabular}{|c|l|c|c|c|}
\hline No & Nama Kriteria & Bobot & Hitungan & $\begin{array}{c}\text { Bobot } \\
\text { Normal }\end{array}$ \\
\hline 5 & Amonia & 5 & $5 /(5+5+5+5+5+5+5)$ & 0.14285714 \\
\hline 6 & Debu & 5 & $5 /(5+5+5+5+5+5+5)$ & 0.14285714 \\
\hline 7 & Timah Hitam & 5 & $5 /(5+5+5+5+5+5+5)$ & 0.14285714 \\
\hline
\end{tabular}

Nilai alternatif terhadap kriteria ini berisi nilai dari masing-masing alternatif terhadap masing - masing kriteria. Nilai-nilai alternatif terhadap kriteria ini didapatkan dari penelitian kimia dengan metode tertentu. Dari metode-metode kimia yang telah dilakukan oleh Pabrik Gula Mojopanggung maka dihasilkan nilai alternatif terhadap kriteria seperti pada tabel VII di mana nama cerobong boiler sebagai alternatifnya dan tabel VIII di mana nama desa di sekitar Pabrik Gula Mojopanggung sebagai alternatifnya di bawah ini:

TABEL VII

NiLAI ALTERNATIF TERHADAP KRITERIA LIMBAH GAS

\begin{tabular}{|c|l|r|r|r|r|}
\hline No & \multicolumn{1}{|c|}{ Alternatif } & $\begin{array}{c}\text { Nitrogen } \\
\text { Dioksida }\end{array}$ & $\begin{array}{c}\text { Sulfur } \\
\text { Dioksida }\end{array}$ & Partikel & Opasitas \\
\hline 1. & Boiler Stork II & 54 & 4.1 & 98 & 5.8 \\
\hline 2. & Boiler Stork I & 80 & 7.4 & 177 & 6.6 \\
\hline 3. & Boiler JTA & 9.3 & 7.9 & 177 & 10.8 \\
\hline
\end{tabular}

TABEL VIII

NilAi Alternatif TerhadAP KRITERIA KUALITAS UdARA AMBIEN

\begin{tabular}{|c|l|r|l|l|l|l|l|l|}
\hline No & Alternatif & $\begin{array}{l}\text { Karbon } \\
\text { Monok } \\
\text { sida }\end{array}$ & $\begin{array}{l}\text { Oksida } \\
\text { Nitrog } \\
\text { en }\end{array}$ & $\begin{array}{l}\text { Sulfur } \\
\text { Dioksi } \\
\text { da }\end{array}$ & $\begin{array}{l}\text { Hidro } \\
\text { gen } \\
\text { Sulfid } \\
\text { a }\end{array}$ & $\begin{array}{l}\text { Amoni } \\
\text { a }\end{array}$ & Debu & $\begin{array}{l}\text { Timah } \\
\text { Hitam }\end{array}$ \\
\hline 1 & Jatimulyo & 0.3 & 0.0099 & 0.11 & 0.05 & 0.703 & 0.137 & 0.061 \\
\hline 2 & $\begin{array}{l}\text { Batangsar } \\
\text { en }\end{array}$ & 1.67 & 0.0107 & 0.0011 & 0.05 & 0.084 & 0.047 & 0.07 \\
\hline 3 & Sidorejo & 0.3 & 0.0151 & 0.0018 & 0.035 & 0.0049 & 0.0622 & 0.061 \\
\hline 4 & $\begin{array}{l}\text { Panggung } \\
\text { rejo }\end{array}$ & 1.7 & 0.0065 & 0.0013 & 0.04 & 0.0245 & 0.0585 & 0.0003 \\
\hline
\end{tabular}

Tabel IX menunjukkan nilai vektor (S) ditentukan dengan mengalikan cara seluruh kriteria dengan alternatif hasil normalisasi atau perbaikan bobot yang bernilai positif untuk kriteria keuntungan (benefit) dan berpangkat negatif untuk kriteria biasa (cost), sedangkan hasil vektor S dari masing masing alternatif diperoleh dari nilai - nilai alternatif terhadap kriteria dipangkatkan dengan masing - masing bobot ternormalisasi kriteria dapat dilihat pada tabel X.

TABEL IX

TABEL VeKTOR S AlternAtiF LIMBAH GAS DARI CEROBONG KeTEL

\begin{tabular}{|c|l|c|c|}
\hline No & Alternatif & Hitungan & Vektor S \\
\hline 1 & $\begin{array}{l}\text { Boiler } \\
\text { Stork II }\end{array}$ & $(54)^{0.25} \cdot(4.1)^{0.25} \cdot(98)^{0.25} \cdot(5.8)^{025}$ & 18.8346659 \\
\hline 2 & $\begin{array}{l}\text { Boiler } \\
\text { Stork I }\end{array}$ & $(80)^{0.25} \cdot(7.4)^{0.25} \cdot(177)^{0.25} \cdot(6.6)^{025}$ & 28.8376408 \\
\hline 3 & Boiler JTA & $(9.3)^{0.25} \cdot(7.9)^{0.25} \cdot(177)^{0.25} \cdot(10.8)^{025}$ & 19.3587257 \\
\hline
\end{tabular}


TABEL X

TABEL VeKTOR S ALTERNATIF KUALITAS UdARA AMBIEN

\begin{tabular}{|c|c|c|c|}
\hline No & Alternatif & Hitungan & Vektor S \\
\hline 1 & Jatimulyo & $\begin{array}{l}(0.3)^{0.14285714} \cdot(0.0099)^{0.14285714} \cdot \\
(0.11)^{0.14285714} \cdot(0.05)^{0.14285714} \cdot \\
(0.703)^{0.14285714} \cdot(0.137)^{0.14285714} \cdot \\
(0.061)^{0.14285714}\end{array}$ & 0.09941374 \\
\hline 2 & $\begin{array}{l}\text { Batangsar } \\
\text { en }\end{array}$ & $\begin{array}{l}(1.67)^{0.14285714} \cdot(0.0107)^{0.14285714} \\
(0.0011)^{0.14285714} \cdot(0.05)^{0.14285714} \\
(0.084)^{0.14285714} \cdot(0.047)^{0.14285714} \\
(0.07)^{0.14285714}\end{array}$ & 0.04299518 \\
\hline 3 & Sidorejo & $\begin{array}{l}(0.3)^{0.14285714} \cdot(0.0151)^{0.14285714} \\
(0.0018)^{0.14285714} \cdot(0.035)^{0.14285714} \\
(0.0049)^{0.14285714} \cdot(0.0622)^{0.14285714} \\
(0.061)^{0.14285714}\end{array}$ & 0.02450478 \\
\hline 4 & $\begin{array}{l}\text { Panggung } \\
\text { rejo }\end{array}$ & $\begin{array}{l}(1.7)^{0.14285714} \cdot(0.0065)^{0.14285714} \\
(0.0013)^{0.14285714} \cdot(0.04)^{0.14285714} \\
(0.0245)^{0.14285714} \cdot(0.0585)^{0.14285714} \\
(0.0003)^{0.14285714}\end{array}$ & 0.01581149 \\
\hline
\end{tabular}

Vektor (V) merupakan preferensi alternative limbah gas dari cerobong ketel yang akan digunakan untuk perankingan dari masing - masing jumlah nilai vektor (S) dengan jumlah seluruh nilai vektor (S) dapat dilihat pada tabel XI.

TABEL XI

TABEl VeKTOR V ALternatif LIMBAH GAS DARI CEROBONG KeTEL

\begin{tabular}{|c|c|c|c|}
\hline No & Alternatif & Hitungan & Vektor V \\
\hline 1 & Boiler Stork II & $\begin{array}{l}18.8346659 /(18.8346659+ \\
28.8376408+19.3587257)\end{array}$ & 0.280984274 \\
& & $28.8376408 /(18.8346659+$ & 0.430213287 \\
\hline 2 & Boiler Stork I & $28.8376408+19.3587257)$ & \\
\hline 3 & Boiler JTA & $\begin{array}{l}19.3587257 /(18.8346659+ \\
28.8376408+19.3587257)\end{array}$ & 0.28880244 \\
\hline
\end{tabular}

Tabel XII menunjukkan nilai vektor V dari masingmasing alternatif diperoleh dari nilai vektor $S$ alternatif dibagi total vektor $\mathrm{S}$. Nilai yang tertinggi adalah peringkat pertama yang artinya merupakan cerobong ketel yang mengeluarkan limbah paling berbahaya. Nilai vektor $\mathrm{V}$ dari masing - masing alternatif diperoleh dari nilai vektor $\mathrm{S}$ alternatif dibagi total vektor S. Nilai yang tertinggi adalah peringkat pertama yang artinya merupakan desa di sekitar Pabrik Gula Mojopanggung dengan kualitas udara ambien paling buruk akibat limbah gas Pabrik Gula Mojopanggung atau desa paling terdampak.

TABEL XII

TABEL VEKTOR V ALternatif KuAlitas UdARA AMBIEN

\begin{tabular}{|l|l|l|l|}
\hline No & Alternatif & \multicolumn{1}{|c|}{ Hitungan } & Vektor V \\
\hline 1 & Jatimulyo & $\begin{array}{l}0.09941374 /(0.09941374+0.0429 \\
9518+0.02450478+0.01581149)\end{array}$ & 0.54406153 \\
\hline 2 & $\begin{array}{l}\text { Batangsar } \\
\text { en }\end{array}$ & $\begin{array}{l}0.04299518 /(0.09941374+0.0429 \\
9518+0.02450478+0.01581149)\end{array}$ & 0.23529968 \\
\hline 3 & Sidorejo & $\begin{array}{l}0.02450478 /(0.09941374+0.0429 \\
9518+0.02450478+0.01581149)\end{array}$ & 0.13410727 \\
\hline 4 & $\begin{array}{l}\text { Panggung } \\
\text { rejo }\end{array}$ & $\begin{array}{l}0.01581149 /(0.09941374+0.0429 \\
9518+0.02450478+0.01581149)\end{array}$ & 0.08653151 \\
\hline
\end{tabular}

\section{B. Analisis dan Desain Sistem}

Manager Quality Assurance sebagai admin dari PTPN X memasukkan kriteria limbah gas dan kualitas udara ambien yang ditentukan oleh PTPN X sesuai dengan kriteria kriteria dari Pergub Jatim No 10 Tahun 2009. Gambar 4 menunjukkan proses bisnis penilaian pencemaran udara. Sistem menyimpan dan mengolah bobot dari kriteria yang dimasukkan admin tersebut. Manager Pengolahan yang bertanggung jawab dalam pengolahan limbah dan juga sebagai pengambil keputusan ini selanjutnya akan memasukkan alternatif dan nilai ke dalam sistem. Sistem aplikasi tersebut nantinya akan memproses nilai-nilai dari setiap cerobong dan desa sebagai alternatif. Kemudian sistem juga akan menampilkan nilai akhir masing-masing alternatif yang nantinya dapat diketahui siapa saja yang yang memiliki nilai tertinggi. Terakhir setelah diproses dalam sistem, nilai atau hasil perangkingan dibuat laporan yang dapat dicetak dan juga grafik untuk mempermudah pembacaan nilai tertinggi. Report dan Grafik ini kemudian akan diberikan kepada General dan juga pada admin dari PTPN X.

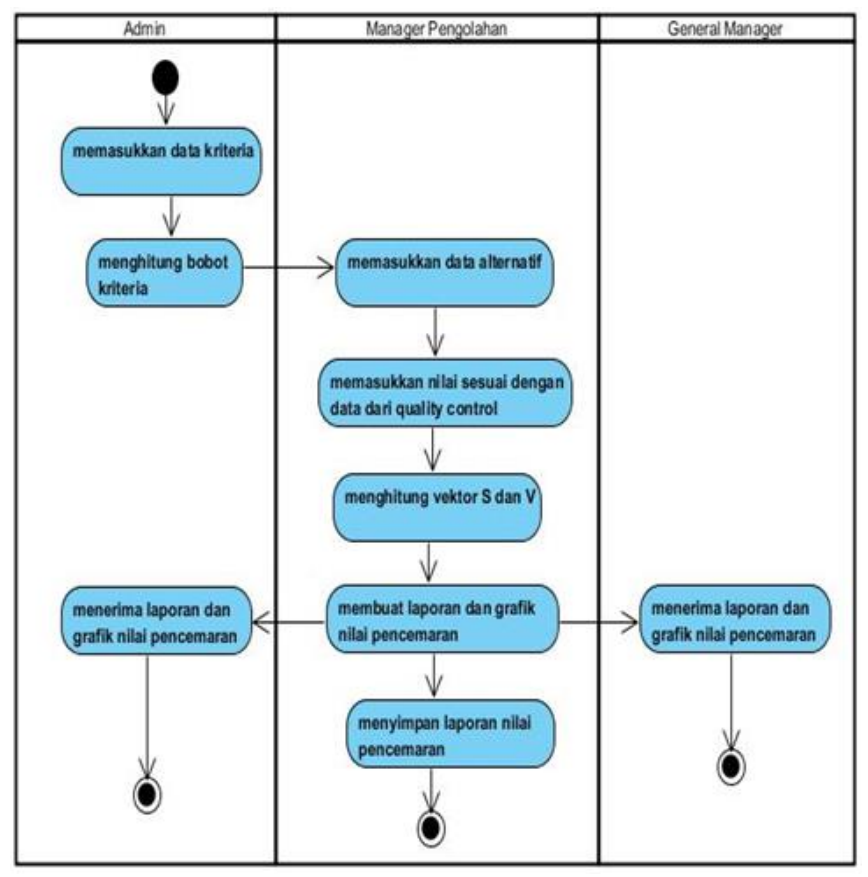

Gambar 4 Activity Diagram Penilaian Pencemaran Udara

Gambar 5 menunjukkan use case diagram yang terdapat dalam sistem pendukung keputusan pencemaran udara. Ada tiga actor yang terlibat yaitu admin yang bertugas memasukkan kriteria pencemaran, manager pengolahan yang bertugas memasukkan data alternatif, dan general manager yang bertugas membaca laporan grafik nilai pencemaran udara. Use case input dan hitung kriteria, input alternatif, hitung vektor $\mathrm{S}$ dan $\mathrm{V}$ merupakan use case utama yang berkaitan dengan proses perhitungan nilai pencemaran udara, sedangkan use case laporan dan grafik berkaitan 
dengan penyajian informasi yang dibutuhkan untuk general manager PG Mojopangung.

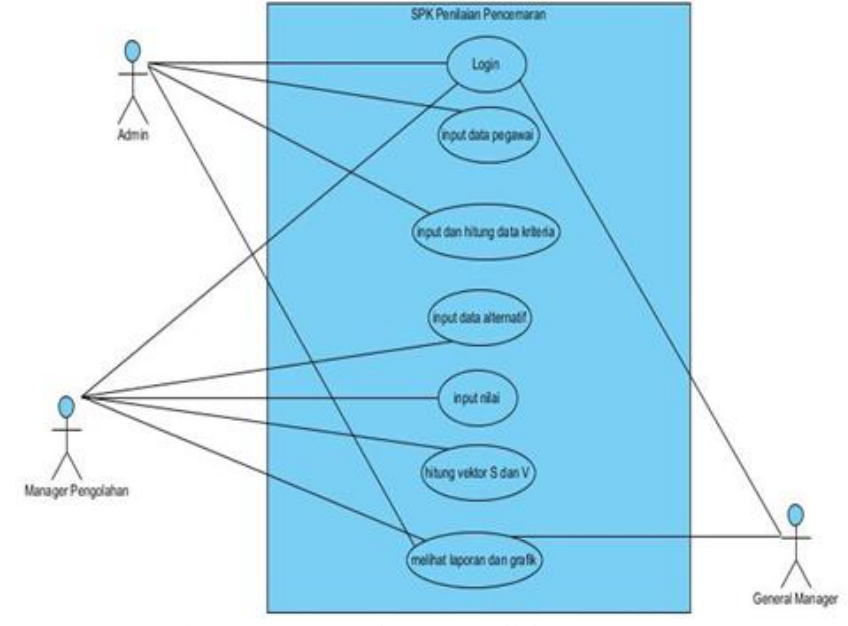

Gambar 5 Use Case Diagram Penilaian Pencemaran Udara

Gambar 6 menunjukkan class diagram yang dibutuhkar untuk proses penilaian pencemaran udara yang berhubungar dengan pabrik adalah class cerobong, penilaian limbah, baku mutu limbah, kriteria cerobong, sedangkan yang berhubungan dengan desa adalah class desa, penilaian ambien, baku mutu ambien, kriteria desa tombol hitung di masing-masing baris kriteria. Sistem akan menghitung normalisasi bobot kriteria per kriteria dan kemudian menampilkannya.

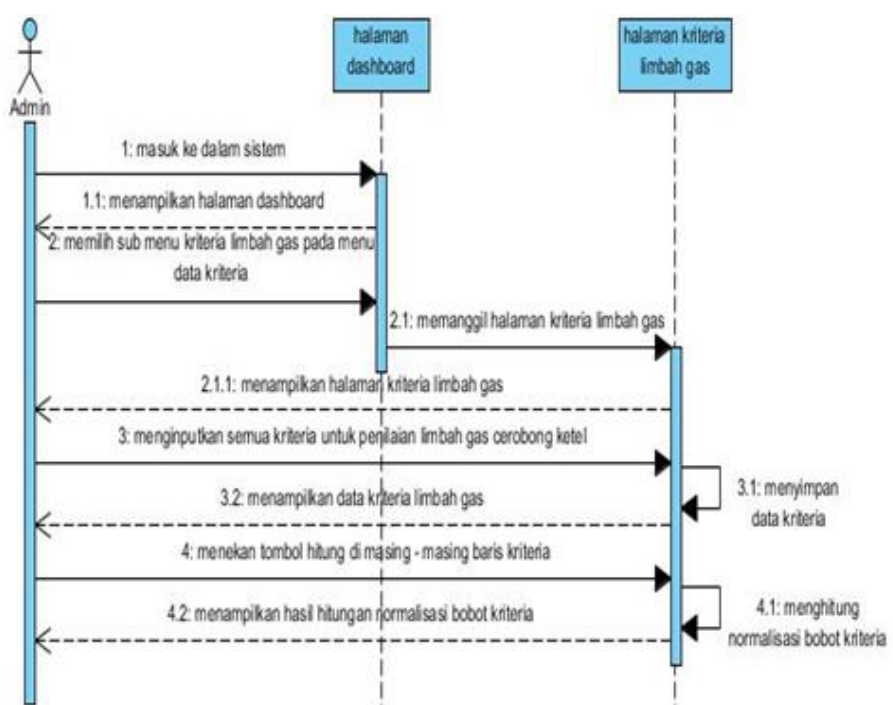

Gambar 7 Sequence Diagam Kriteria Limbah Gas
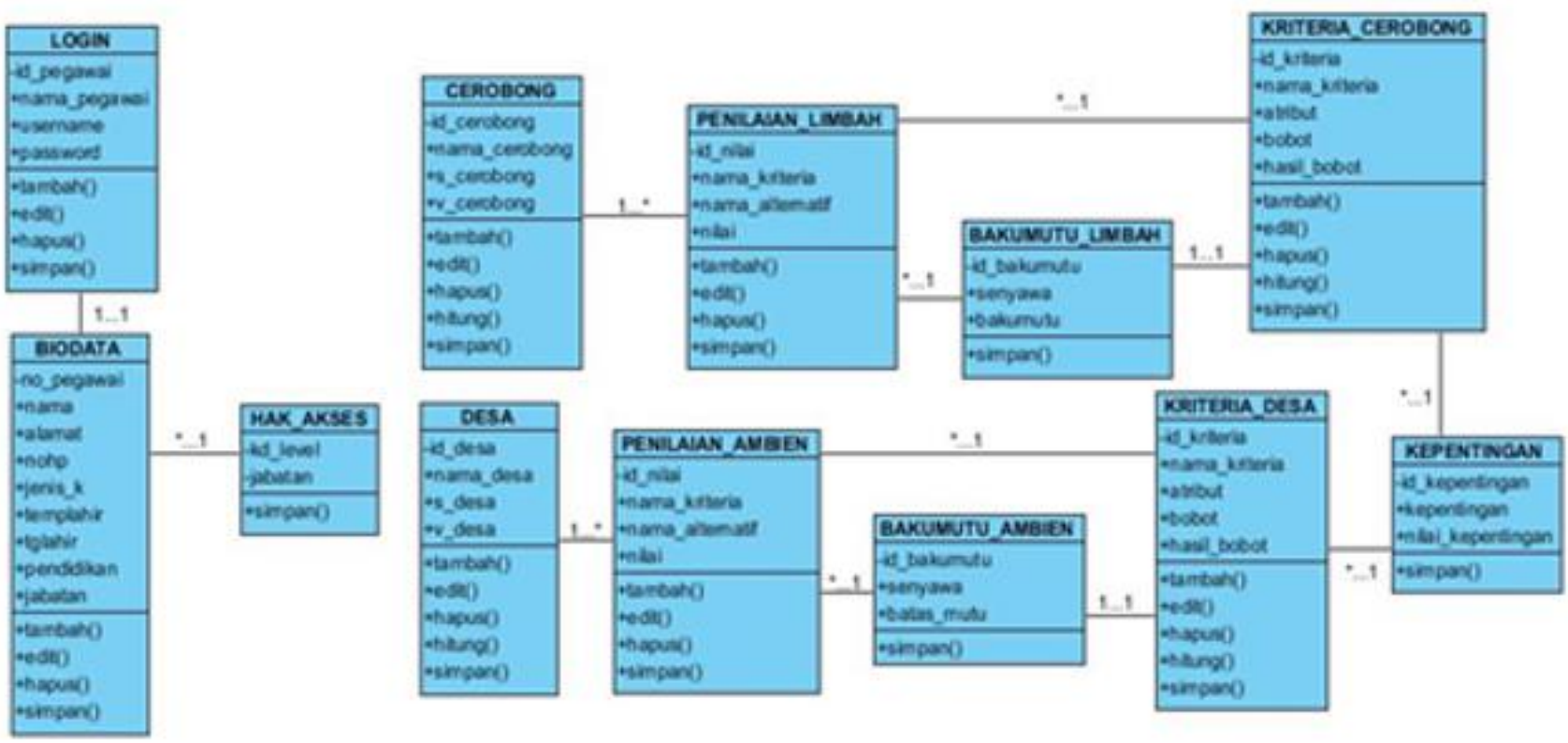

Gambar 6 Class Diagram Penilaian Pencemaran Udara

Gambar 7 menampilkan sequence diagram kriteria limbah gas. Setelah logi, Admin memilih sub menu kriteria limbah gas pada menu data kriteria. Sistem akan menampilkan halaman kriteria limbah gas. Admin menginputkan semua kriteria untuk penilaian limbah gas cerobong ketel. Sistem akan menyimpan dan kemudian menampilkan data kriteria limbah gas. Admin menekan
Gambar 8 menampilkan sequence diagram kriteria kualitas udara. Setelah login, Admin memilih sub menu kriteria kualitas udara pada menu data kriteria. Sistem akan menampilkan halaman kriteria kualitas udara. Admin menginputkan semua kriteria untuk penilaian kualitas udara ambien di desa sekitar pabrik gula Mojopanggung. Sistem akan menyimpan dan kemudian menampilkan data kriteria kualitas udara. Admin menekan tombol hitung di masing- 
masing baris kriteria. Sistem akan menghitung normalisasi bobot kriteria per kriteria dan kemudian menampilkannya.

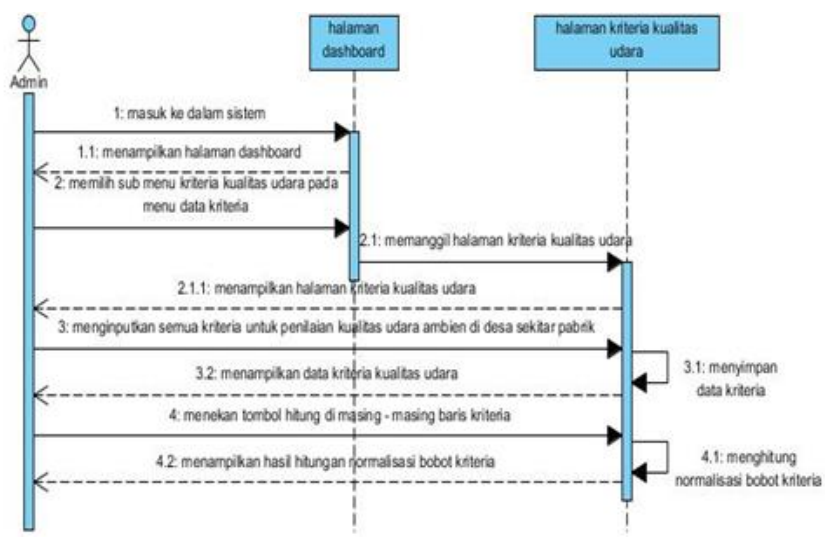

Gambar 8 Sequence Diagam Kriteria Kualitas Udara

Gambar 9 menampilkan sqequence diagram alternatif limbah gas. Setelah login, Manager Pengolahan memilih sub menu data cerobong pada menu data alternatif. Sistem kemudian akan menampilkan halaman data cerobong. Manager Pengolahan memasukkan semua alternatif untuk penilaian limbah gas cerobong ketel. Sistem akan menyimpan data cerobong dan kemudian menampilkannya.

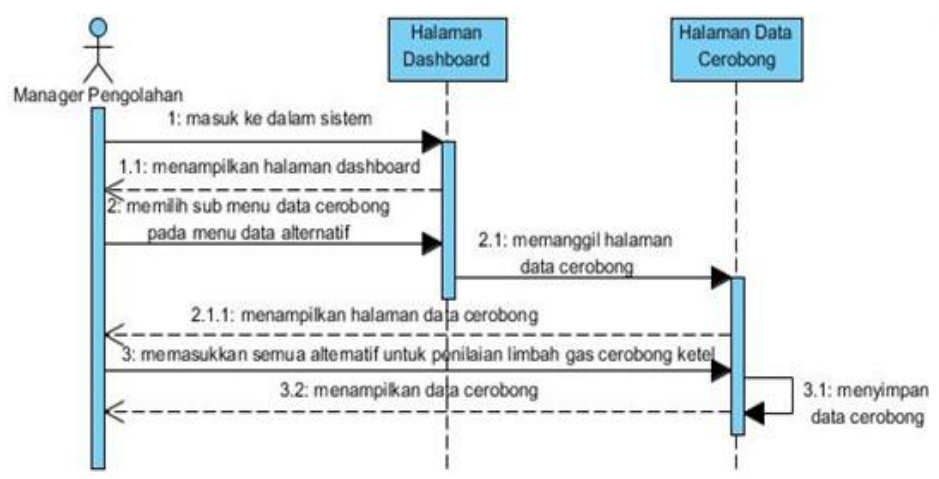

Gambar 9 Sequence Diagam Alternatif Limbah Gas

Gambar 10 menampilkan sequence diagram alternatif kualitas udara. Setelah login, Manager Pengolahan memilih sub menu data desa pada menu data alternatif. Sistem kemudian akan menampilkan halaman data desa. Manager Pengolahan memasukkan semua alternatif untuk penilaian kualitas udara ambien desa di sekitar pabrik gula Mojopanggung. Sistem akan menyimpan data desa dan kemudian menampilkannya.

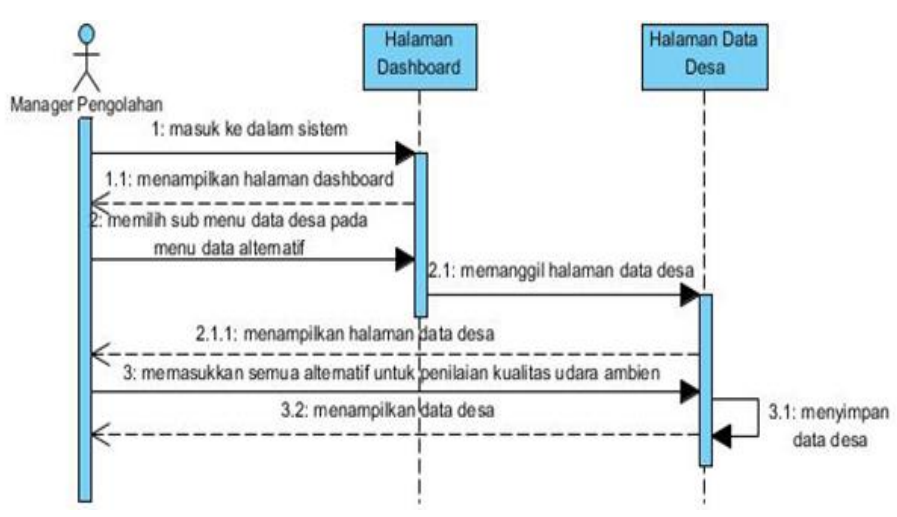

Gambar 10 Sequence Diagam Alternatif Kualitas Udara

Gambar 11 menampilkan sequence diagram nilai limbah gas. Setelah login, Manager Pengolahan memilih sub menu penilaian limbah gas pada menu penilaian pencemaran. Sistem kemudian akan menampilkan halaman penilaian limbah gas. Manager Pengolahan memasukkan nilai dari penilaian gas cerobong ketel. Sistem akan menyimpan data penilaian limbah gas cerobong ketel dan kemudian menampilkannya.

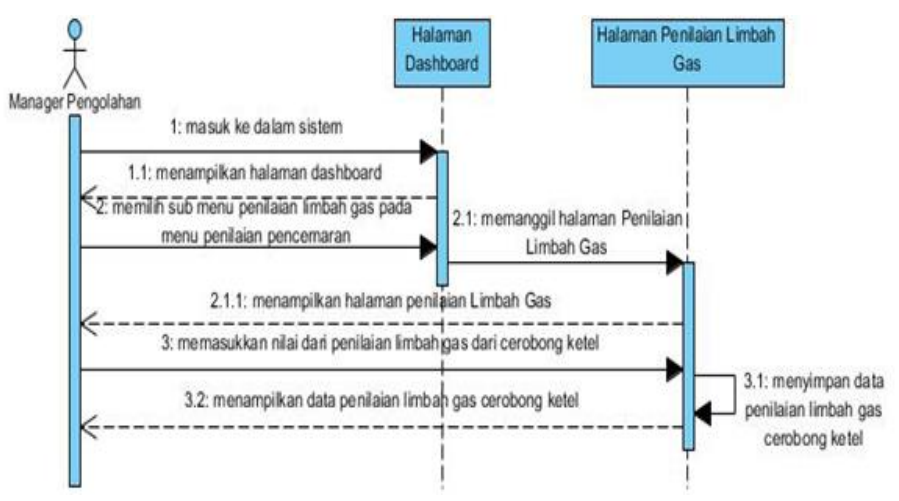

Gambar 11 Sequence Diagam Nilai Limbah Gas

Gambar 12 menampilkan sequence diagram nilai kulitas udara. Setelah login, Manager Pengolahan memilih sub menu penilaian kualitas udara pada menu penilaian pencemaran. Sistem kemudian akan menampilkan halaman penilaian kualitas udara. Manager Pengolahan memasukkan nilai dari penilaian kualitas udara ambien dari desa di sekitar pabrik gula Mojopanggung. Sistem akan menyimpan data penilaian kualitas udara ambien tersebut dan kemudian menampilkannya. 


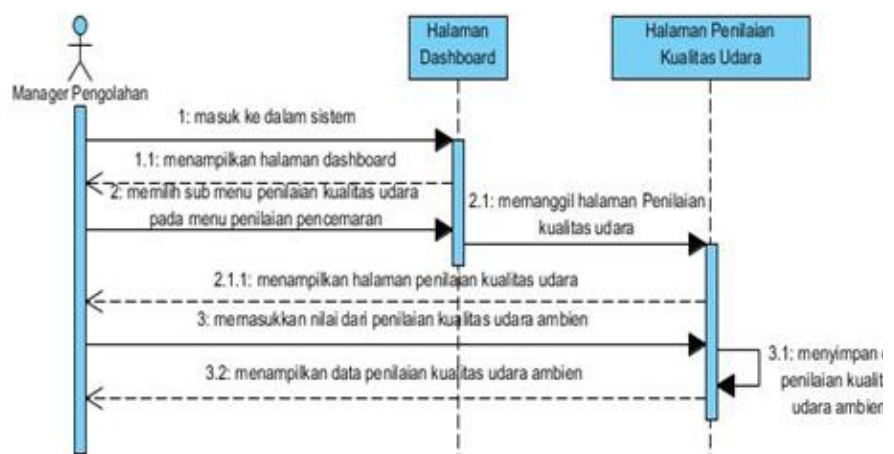

Gambar 12 Sequence Diagam Nilai Kualitas Udara

Gambar 13 menampilkan sequence diagram hitung Vektor S dan V limbah gas. Setelah login, Manager Pengolahan memilih sub menu data cerobong pada menu data kriteria. Sistem kemudian akan menampilkan halaman data cerobong. Manager Pengolahan menekan tombol hitung di sebelah kolom vektor S pada semua baris alternatif maka sistem akan menampilkan hasil hitungan dari vektor $S$. Manager Pengolahan kemudian menekan tombol hitung di sebelah kolom vektor $\mathrm{V}$ pada semua baris alternatif maka sistem akan menampilkan hasil hitungan dari vektor $\mathrm{V}$

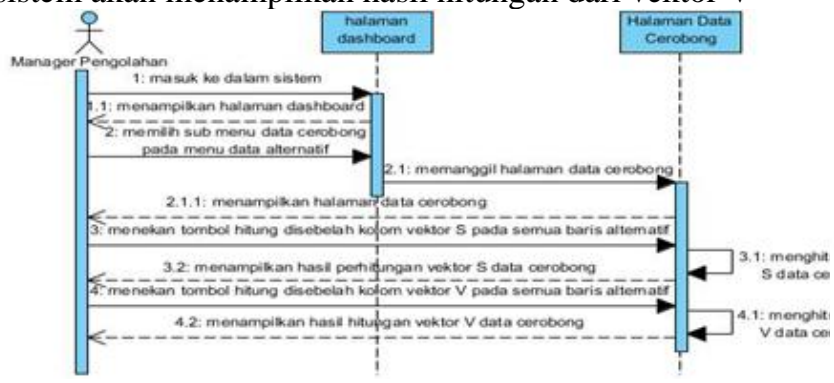

Gambar 13 Sequence Diagam Hitung Vektor S dan V Limbah Gas

Gambar 14 menampilkan sequence diagram hitun Vektor S dan V kualitas udara. Setelah melakukan login Manager Pengolahan memilih sub menu data desa padi menu data kriteria. Sistem kemudian akan menampilkarı halaman data desa. Manager Pengolahan menekan tombol hitung di sebelah kolom vektor S pada semua baris alternatif maka sistem akan menampilkan hasil hitungan dari vektor $\mathrm{S}$. Manager Pengolahan kemudian menekan tombol hitung di sebelah kolom vektor $\mathrm{V}$ pada semua baris alternatif maka sistem akan menampilkan hasil hitungan dari vektor $\mathrm{V}$.

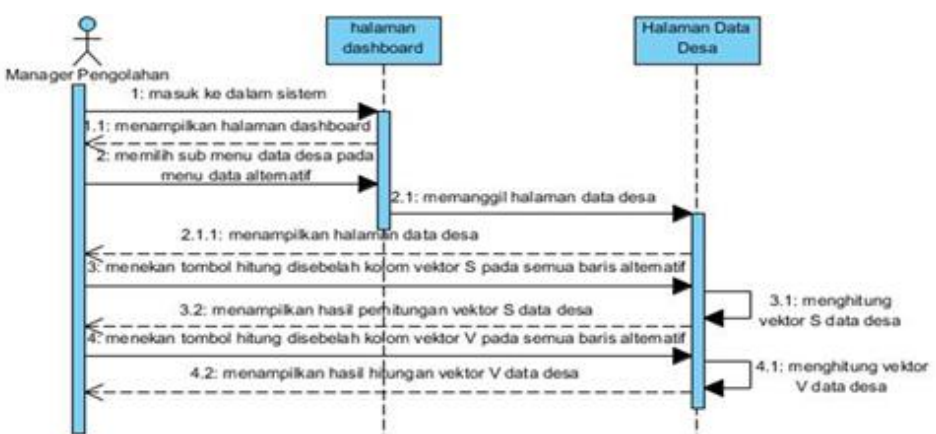

Gambar 14 Sequence Diagam Hitung Vektor S dan V Kualitas Udara

Gambar 15 menampilkan sequence diagram report limbah gas. Setelah melakukan login, General Manager memilih sub menu laporan limbah gas cerobong ketel pada menu laporan. Sistem akan menampilkan laporan penilaian limbah gas cerobong ketel. General Manager menekan tombol cetak. Sistem akan menampilkan laporan penilaian limbah gas cerobong ketel dalam bentuk pdf. Selanjutnya untuk melihat grafik penilaian limbah gas cerobong ketel, General Manager memilih sub menu grafik cerobong pada menu grafik dan Sistem meresponnya dengan menampilkan grafik penilaian limbah gas cerobong ketel. Hal ini juga dilakukan oleh Admin dan Manager Pengolahan ketika melihat laporan dan grafik penilaian limbah gas cerobong ketel.

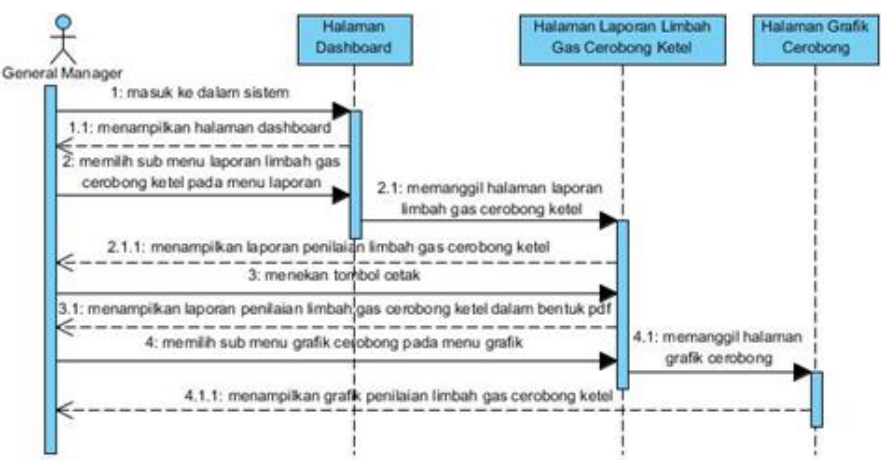

Gambar 15 Sequence Diagam Report Limbah Gas

Gambar 16 menampilkan sequence diagram report kualitas udara ambien. Setelah melakukan login, General Manager menekan tombol cetak. Sistem akan menampilkan laporan penilaian kualitas udara ambien desa di sekitar pabrik gula Mojopanggung dalam bentuk pdf. Selanjutnya untuk melihat grafik penilaian kualitas udara ambien desa di sekitar pabrik gula Mojopanggung, General Manager memilih sub menu grafik kualitas udara pada menu grafik dan Sistem meresponnya dengan menampilkan grafik penilaian kualitas udara ambien desa di sekitar pabrik gula Mojopanggung. Hal ini juga dilakukan oleh Admin dan Manager Pengolahan ketika melihat laporan dan grafik penilaian kualitas udara ambien desa di sekitar pabrik gula Mojopanggung. 


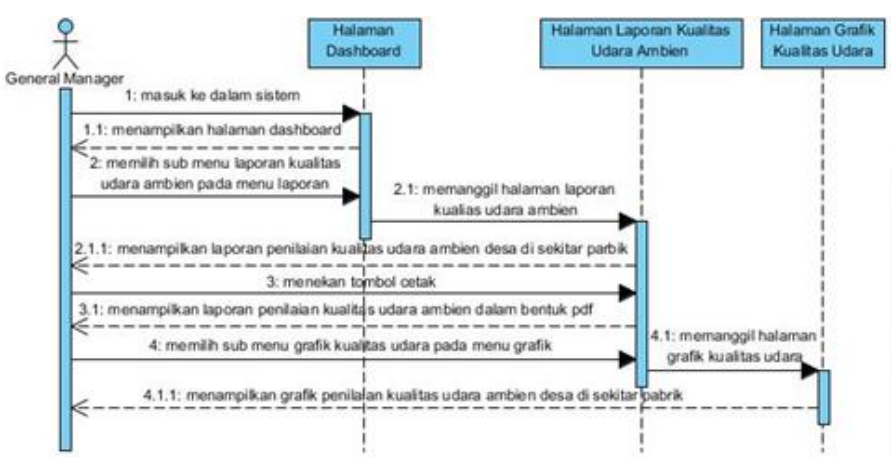

Gambar 16 Sequence Diagam Report Kualitas Udara Ambien

\section{Implementasi Sistem}

Gambar 17 merupakan tampilan form data kriteria limbah gas yang berfungsi untuk melakukan manipulasi data kriteria limbah gas, dan menghitung hasil pembobotan atau normalisasi bobot kriteria limbah gas.

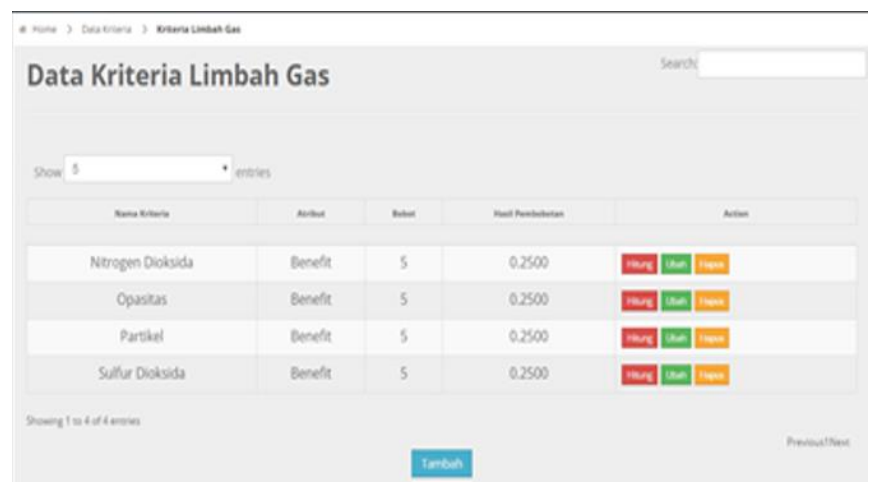

Gambar 17 Form Kriteria Limbah Gas

Gambar 18 merupakan tampilan form data kriteria kualitas udara yang berfungsi untuk melakukan manipulasi data kriteria kualitas udara, dan menghitung hasil pembobotan atau normalisasi bobot kriteria kualitas udara.

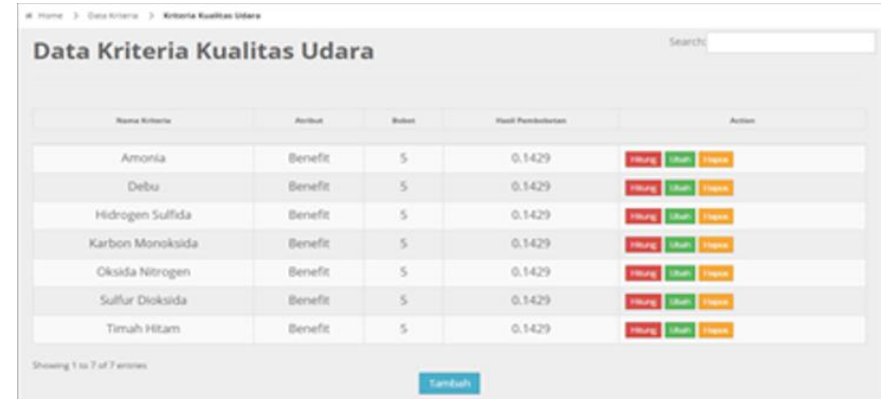

Gambar 18 Form Kriteria Kualitas Udara
Gambar 19 merupakan tampilan form alternatif cerobong yang berfungsi untuk melakukan manipulasi data alternatif cerobong, menghitung vektor $\mathrm{S}$, dan menghitung vektor $\mathrm{V}$.

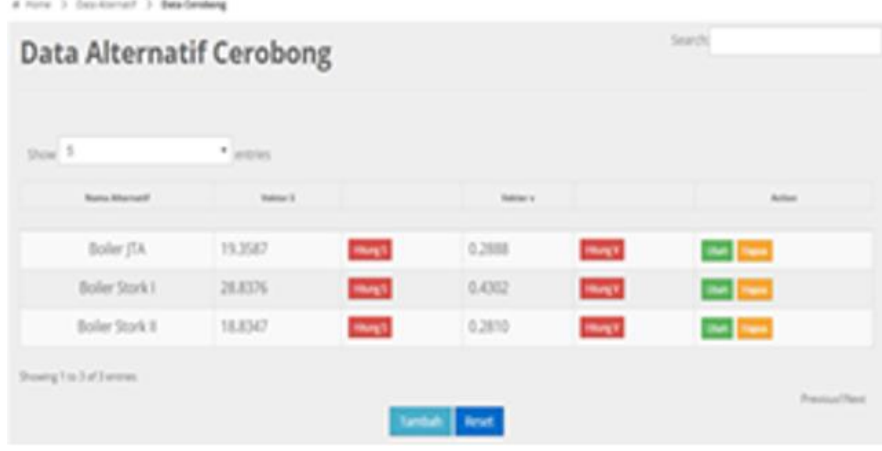

Gambar 19 Form Alternatif Cerobong

Gambar 20 merupakan tampilan form alternatif desa yang berfungsi untuk melakukan manipulasi data alternatif cerobong, menghitung vektor $\mathrm{S}$, dan menghitung vektor $\mathrm{V}$.

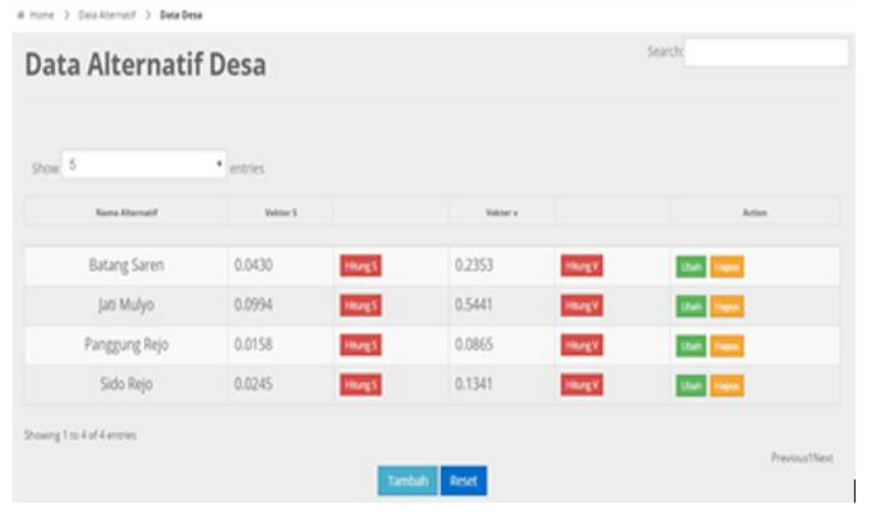

Gambar 20 Form Alternatif Desa

Gambar 21 adalah merupakan tampilan form penilaian limbah gas yang berfungsi untuk melakukan manipulasi data penilaian limbah gas.

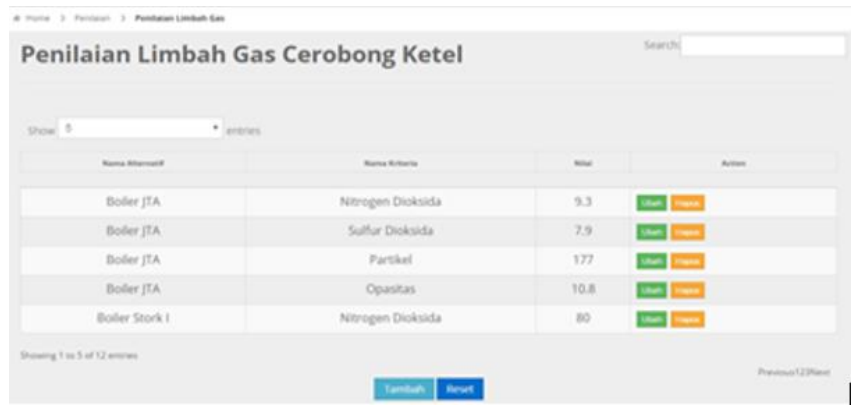

Gambar 21 Form Penilaian Limbah Gas 
Gambar 22 merupakan tampilan form penilaian kualitas udara ambien yang berfungsi untuk melakukan manipulasi data penilaian limbah kualitas udara ambien.

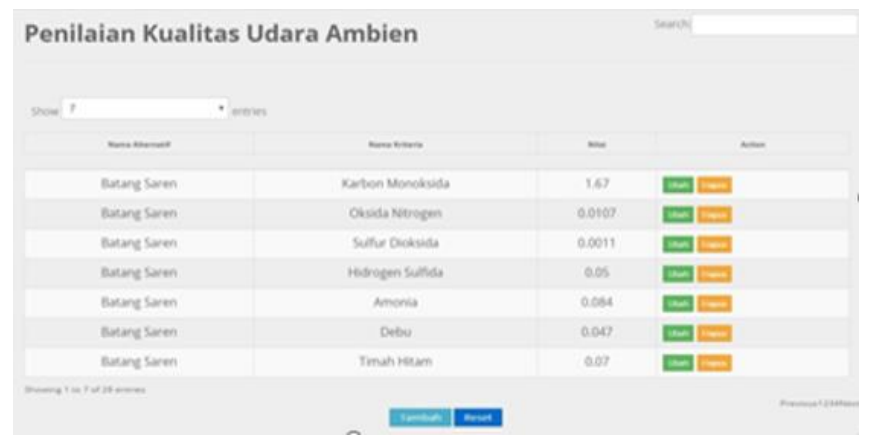

Gambar 22 Form Penilaian Limbah Kualitas Udara Ambien

Gambar 23 merupakan report penilaian limbah gas cerobong ketel yang berfungsi untuk menampilkan informasi penilaian limbah gas cerobong ketel.

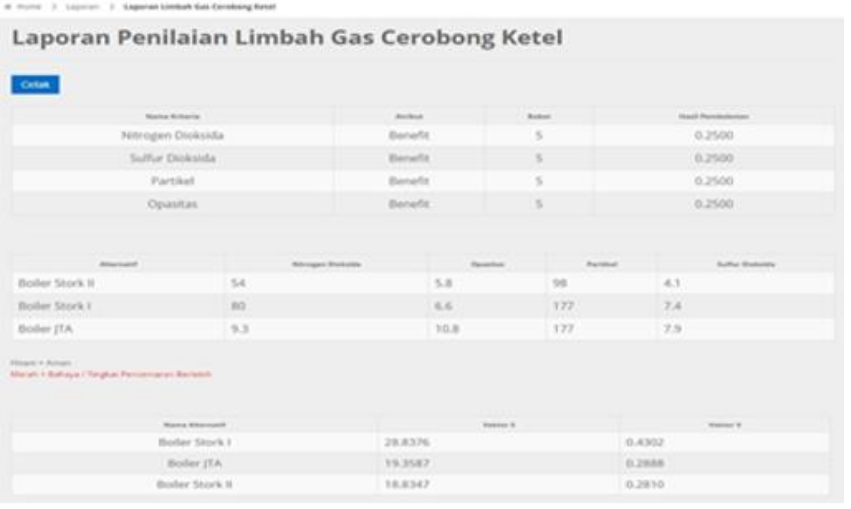

Gambar 23 Report Penilaian Limbah Gas Cerobong Ketel

Gambar 24 merupakan report penilaian penilaian kualitas udara ambien yang berfungsi untuk menampilkan informasi tentang penilaian kualitas udara ambien.

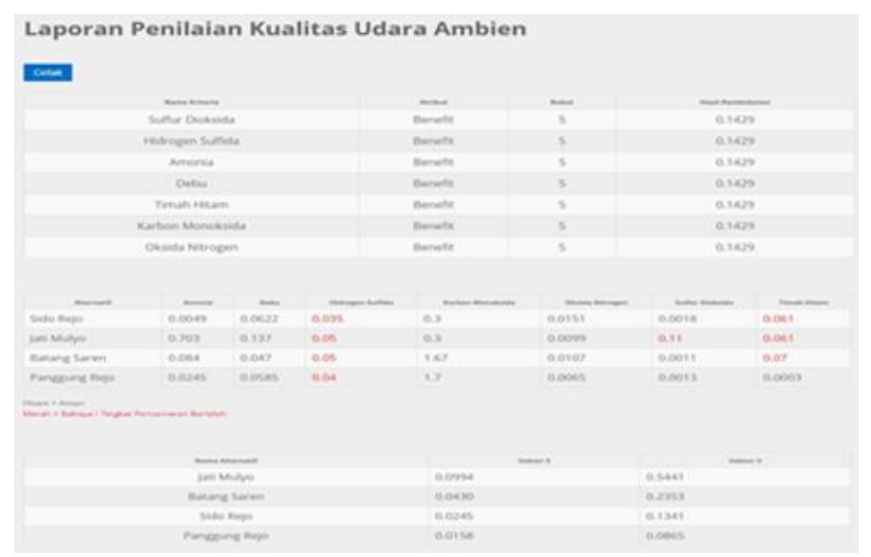

Gambar 24 Report Penilaian Kualitas Udara Ambien
Gambar 25 merupakan laporan penilaian limbah gas cerobong ketel yang menampilkan informasi tentang hasil perhitungan pembobotan kriteria, nilai alternatif kriteria dan hasil perhitungan vektor $\mathrm{S}$ dan vektor V. Dari laporan tersebut terlihat bahwa berdasarkan hasil perhitungan, nilai vektor $\mathrm{V}$ tertinggi adalah cerobong boiler stork I. Hal ini berarti bahwa cerobong boiler stork I merupakan cerobong yang menghasilkan pencemaran udara paling banyak di pabrik gula Mojopanggung.

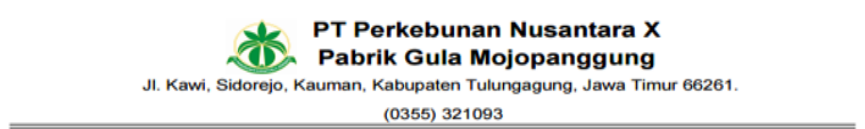

PENILAIAN LIMBAH GAS DARI CEROBONG KETEL
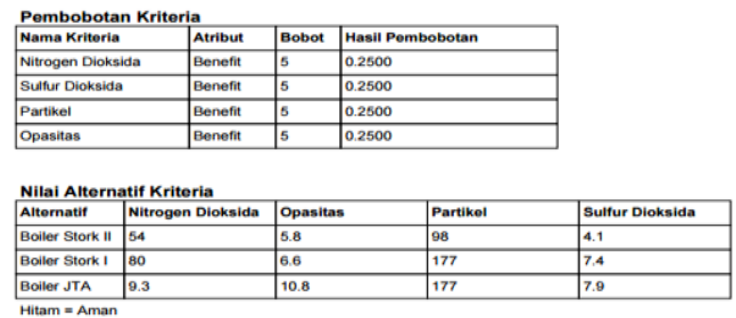

Hitam $=$ Aman
Merah $=$ Bahaya $/$ Tingkat Pencemaran Berlebi

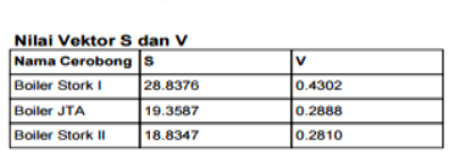

Gambar 25 Laporan Penilaian Limbah Gas Cerobong Ketel

Gambar 26 merupakan grafik penilaian limbah gas cerobong ketel. Pada grafik tersebut terlihat bahwa yang memiliki nilai vektor $\mathrm{V}$ paling tinggi adalah cerobong Boiler Stork I. Hal ni berarti bahwa cerobong Boiler Stork I merupakan cerobong yang menghasilkan pencemaran udara paling banyak di pabrik gula Mojopanggung diantara cerobong lainnya.

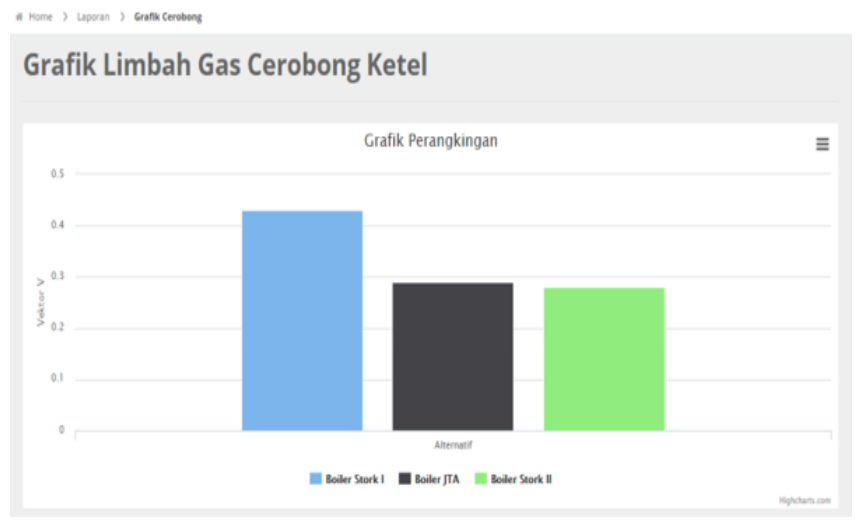

Gambar 26 Grafik Penilaian Limbah Gas Cerobong Ketel 
Gambar 27 merupakan laporan penelitian kualitas udara ambien desa di sekitar PG Mojopanggung. Dari report tersebut terlihat bahwa nilai vektor $\mathrm{V}$ tertinggi adalah milik desa Jatimulyo. Hal ini berarti bahwa Jatimulyo merupakan desa paling buruk kualitas udara ambiennya atau merupakan desa yang paling terdampak oleh pencemaran udara dari PG Mojopanggung.

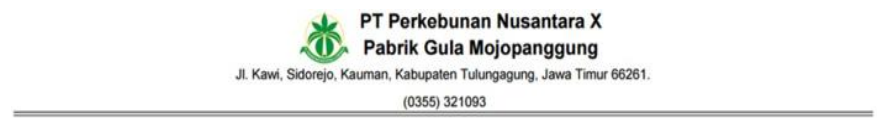

PENILAIAN KUALITAS UDARA AMBIEN DESA DI SEKITAR PG MOJOPANGGUNG
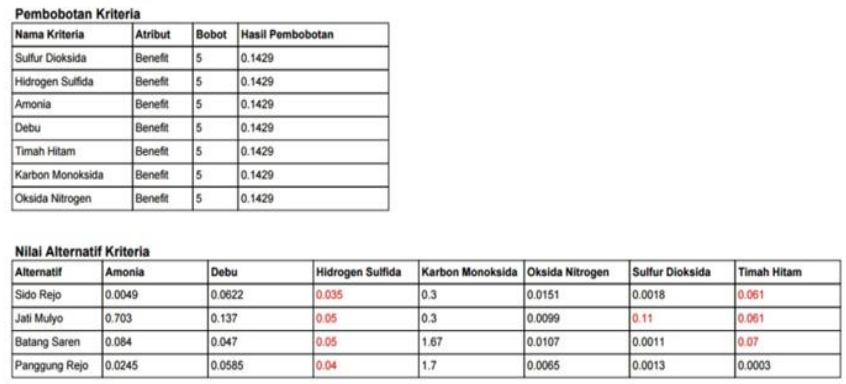

Heam = Aman

Merah = Bahaya / Tinglat Pencomaran Beretebih

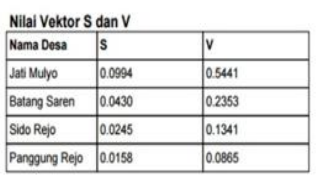

Gambar 27 Laporan Penilaian Kualitas Udara Ambien Desa di Sekitar PG Mojopanggung

Gambar 28 merupakan grafik penilaian kualitas udara ambien desa di sekitar PG Mojopanggung. Pada grafik tersebut terlihat nilai vektor $\mathrm{V}$ paling tinggi adalah desa Jatimulyo. Hal ini berarti bahwa Jatimulyo merupakan desa yang memiliki kualitas udara ambien paling buruk atau desa Jatimulyo merupakan desa yang paling terdampak oleh pencemaran udara PG Mojopanggung.

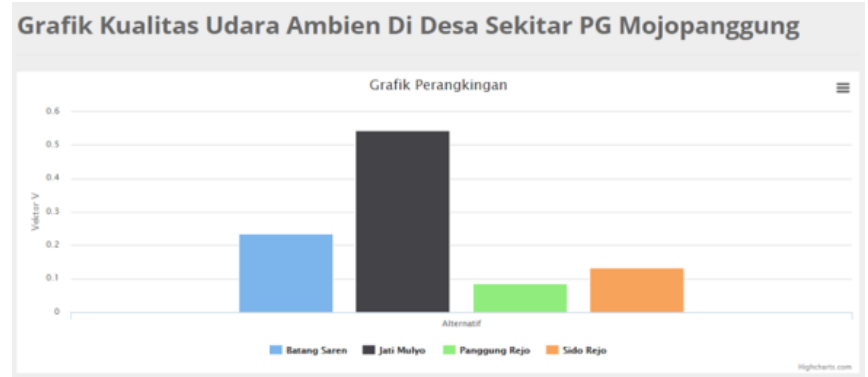

Gambar 28 Grafik Penilaian Kualitas Udara Ambien di Desa Sekitat PG Mojopanggung

\section{Pembahasan}

Berdasarkan penelitian yang dilakukan maka dihasilkan nilai vektor $\mathrm{S}$ dan nilai vektor $\mathrm{V}$ alternatif limbah gas. Pada tabel XIII ditunjukkan bahwa nilai vektor $\mathrm{V}$ tertinggi adalah cerobong boiler stork I yang berarti bahwa cerobong boiler stork I adalah cerobong yang mengeluarkan limbah gas paling banyak dibandingkan dengan cerobongcerobong lainnya. Namun aman tidaknya cerobong tidak dapat mengacu pada hasil vektor $\mathrm{V}$ melainkan harus membandingkan nilai pada penilaian-penilaian pada senyawa- senyawa dengan nilai baku mutu yang telah ditentukan oleh Pergub Jatim No 10 Tahun 2009

TABEL XIII

TABEL VEKTOR S DAN VEKTOR V ALTERNATIF LIMBAH GAS

\begin{tabular}{|l|c|c|}
\hline \multicolumn{1}{|c|}{ Nama Alternatif } & Vektor S & Vektor V \\
\hline Boiler Stork I & 28.8376408 & 0.430213287 \\
\hline Boiler JTA & 19.3587257 & 0.280984274 \\
\hline Boiler Stork II & 18.8346659 & 0.28880244 \\
\hline
\end{tabular}

Jika membandingkan nilai dari masing - masing alternatif pada tabel XIV dengan nilai baku mutu yang ada pada tabel XV dapat dikatakan bahwa semua kadar senyawa dari limbah gas masing-masing cerobong boiler yang ada di PG Mojopanggung masih dalam kategori aman karena tidak melebihi dari nilai baku mutu yang telah ditentukan. Cerobong Boiler Stork memiliki kapasitas gas buang 20 ton/jam sedangkan cerobong Boiler JTA memiliki kapasitas gas buang 40 ton/jam. Sehingga perbedaan nilai vektor V pada cerobong Boile Stork I yang mencolok dapat disebabkan oleh kualitas dan usia dari cerobong tersebut. Solusi yang dapat ditawarkan untuk mengatasi hal ini adalah bekerjasama dengan bagian instalasi melakukan pemeriksaan dan perawatan intensif pada cerobongcerobong tersebut

TABEL XIV

NiLAi BAKU Mutu Limbah GAS DARI CEROBONG KeTEL

\begin{tabular}{|c|l|c|r|}
\hline No & \multicolumn{1}{|c|}{ Parameter } & Satuan & Baku Mutu \\
\hline $\mathbf{1}$ & Partikuler & $\mathrm{mg} / \mathrm{nm}^{3}$ & 250 \\
\hline $\mathbf{2}$ & Sulfur Dioksida $\left(\mathrm{SO}_{2}\right)$ & $\mathrm{mg} / \mathrm{nm}^{3}$ & 600 \\
\hline $\mathbf{3}$ & Nitrogen Dioksida $\left(\mathrm{NO}_{2}\right)$ & $\mathrm{mg} / \mathrm{nm}^{3}$ & 800 \\
\hline $\mathbf{4}$ & Opasitas & $\%$ & 30 \\
\hline
\end{tabular}

Sumber : Pergub Jatim No.10 Tahun 2009

TABEL XV

NILAI ALTERNATIF TERHADAP KRITERIA LIMBAH GAS

\begin{tabular}{|l|r|r|r|r|}
\hline \multicolumn{1}{|c|}{ Alternatif } & $\begin{array}{c}\text { Nitrogen } \\
\text { Dioksida }\end{array}$ & $\begin{array}{c}\text { Sulfur } \\
\text { Dioksida }\end{array}$ & Partikel & Opasitas \\
\hline Boiler Stork II & 54 & 4.1 & 98 & 5.8 \\
\hline Boiler Stork I & 80 & 7.4 & 177 & 6.6 \\
\hline Boiler JTA & 9.3 & 7.9 & 177 & 10.8 \\
\hline
\end{tabular}

Berdasarkan penelitian yang dilakukan maka dihasilkan nilai pada tabel XVI. Pada tabel tersebut ditunjukkan bahwa nilai vektor $\mathrm{V}$ tertinggi adalah desa Jatimulyo yang artinya desa Jatimulyo adalah desa yang paling buruk kualitas udara ambiennya atau desa yang paling terdampak oleh limbah gas dari PG Mojopanggung dibandingkan dengan desa-desa 
lainnya. Namun aman tidaknya kualitas udara ambien pada desa-desa di sekitar PG Mojopanggung tidak dapat mengacu pada hasil vektor $\mathrm{V}$ melainkan harus membandingkan nilai pada penilaian-penilaian pada senyawa-senyawa sesuai dengan baku mutu yang telah ditentukan oleh Pergub Jatim No 10 Tahun 2009. Informasi grafis tentang penilaian kualitas udara ambien desa disajikan pada gambar 29.

TABEL XVI

NILAI VEKTOR S DAN VEKTOR V ALTERNATIF LIMBAH GAS

\begin{tabular}{|l|c|c|}
\hline \multicolumn{1}{|c|}{ Nama Alternatif } & Vektor S & Vektor V \\
\hline Jatimulyo & 0.09941374 & 0.54406153 \\
\hline Batangsaren & 0.04299518 & 0.23529968 \\
\hline Sidorejo & 0.02450478 & 0.13410727 \\
\hline Panggungrejo & 0.01581149 & 0.08653151 \\
\hline
\end{tabular}

Grafik Perangkingan

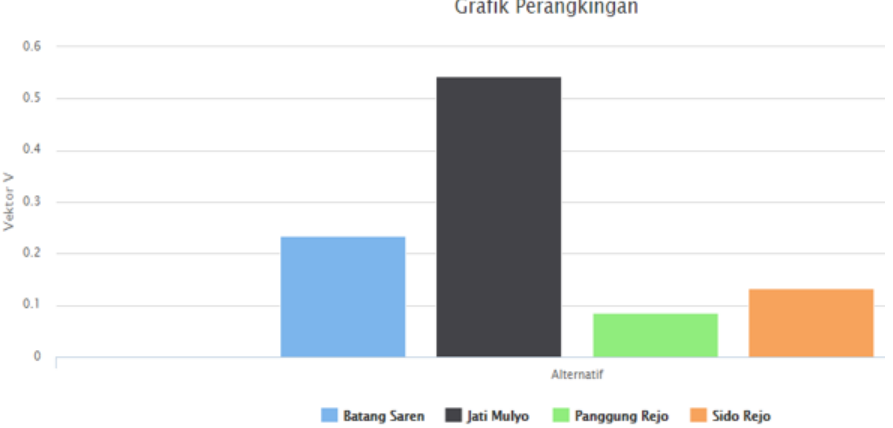

Gambar 29 Grafik Penilaian Kualitas Udara Ambien Desa

Berdasarkan tabel XVII dan XVIII dapat disimpulkan bahwa senyawa yang menjadi polutan gas udara ambien utama di desa sekitar Pabrik Gula Mojopanggung adalah gas hidrogen sulfida $\left(\mathrm{H}_{2} \mathrm{~S}\right)$ dan timah hitam $(\mathrm{Pb})$. Hal tersebut dimungkinkan saat pengukuran kualitas udara ambien dilapangan adalah saat dimana cerobong Sulfitir mengeluarkan limbahnya berupa gas buang yang bersifat insidental saat terjadi fluktuasi aliran nira, karena kualitas dari cerobong atau mungkin dari penguapan dari limbah limbah cari. Gas buang dari cerobong sulfitir berasal dari hasil sampingan proses sulfitasi atau pemurnian nira. Hidrogen sulfida berfungsi untuk membantu penggumpalan gula. Hidrogen sulfida ini nantinya akan keluar bersama hasil sampingan proses sulfitasi lainnya. Sedangkan tingginya nilai polutan timah hitam berasal dari cerobong yang logamnya mulai mengelupas dan ikut bersama senyawa - senyawa sisa proses pembakaran atau proses sulfitasi mengingat usia cerobong yang sudah tua.

Dengan demikian, keadaan kualitas udara ambien dari desa-desa yang ada di sekitar PG Mojopanggung cenderung masih dapat dikatakan cenderung aman karena selisih kelebihan nilai polutan udara dan baku mutu yang ditetapkan relatif sangat sedikit. Sebagai upaya untuk mencegah semakin besarnya polutan udara maka PG Mojopanggung melakukan berbagai macam pengolahan limbah pabrik. Selain itu solusi lain yang dapat ditawarkan untuk mengatasi semakin besarnya polutan udara adalah bekerjasama dengan bagian instalasi melakukan pemeriksaan dan perawatan intensif pada cerobongcerobong tersebut.

TABEL XVII

NILAi AlternatiF KUANTITATIF TERHADAP KRITERIA KUALITAS UdARA

\begin{tabular}{|l|r|r|r|r|r|r|r|}
\hline \multicolumn{1}{|c|}{ Alternatif } & $\mathbf{C O}$ & $\mathbf{N O}_{\mathbf{x}}$ & $\mathbf{S O}_{\mathbf{2}}$ & $\mathbf{H}_{\mathbf{2}} \mathbf{S}$ & $\mathbf{N H}_{\mathbf{3}}$ & $\begin{array}{c}\mathbf{D e b} \\
\mathbf{u}\end{array}$ & $\mathbf{P b}$ \\
\hline Jatimulyo & 0.30 & 0.00 & 0.11 & 0.05 & 0.70 & 0.13 & 0.06 \\
& 00 & 99 & 00 & 00 & 30 & 70 & 10 \\
\hline Batangsaren & 1.67 & 0.01 & 0.00 & 0.05 & 0.08 & 0.04 & 0.07 \\
& 00 & 07 & 11 & 00 & 40 & 70 & 00 \\
\hline Sidorejo & 0.30 & 0.01 & 0.00 & 0.03 & 0.00 & 0.06 & 0.06 \\
& 00 & 51 & 18 & 50 & 49 & 22 & 10 \\
\hline Panggungrejo & 1.70 & 0.00 & 0.00 & 0.04 & 0.02 & 0.05 & 0.00 \\
& 00 & 65 & 13 & 00 & 45 & 85 & 03 \\
\hline
\end{tabular}

TABEL XVIII

NilAi Alternatif KuAlitatif TERHADAP Kriteria KuAlitas UdARA

\begin{tabular}{|l|c|c|c|c|c|c|c|}
\hline Alternatif & CO & NO $_{\mathbf{x}}$ & $\mathbf{S O}_{2}$ & $\mathbf{H}_{\mathbf{2}} \mathbf{S}$ & $\mathbf{N H}_{\mathbf{3}}$ & $\begin{array}{c}\text { Deb } \\
\mathbf{u}\end{array}$ & $\mathbf{P b}$ \\
\hline Jatimulyo & $\begin{array}{c}\mathrm{A} \\
\text { man }\end{array}$ & $\begin{array}{c}\mathrm{A} \\
\text { man }\end{array}$ & $\begin{array}{c}\mathrm{Ba} \\
\text { haya }\end{array}$ & $\begin{array}{c}\mathrm{Ba} \\
\text { haya }\end{array}$ & $\begin{array}{c}\mathrm{A} \\
\text { man }\end{array}$ & $\begin{array}{c}\mathrm{A} \\
\text { man }\end{array}$ & $\begin{array}{c}\text { Ba } \\
\text { haya }\end{array}$ \\
\hline Batangsaren & $\begin{array}{c}\mathrm{A} \\
\text { man }\end{array}$ & $\begin{array}{c}\mathrm{A} \\
\text { man }\end{array}$ & $\begin{array}{c}\mathrm{A} \\
\text { man }\end{array}$ & $\begin{array}{c}\mathrm{Ba} \\
\text { haya }\end{array}$ & $\begin{array}{c}\mathrm{A} \\
\text { man }\end{array}$ & $\begin{array}{c}\mathrm{A} \\
\text { man }\end{array}$ & $\begin{array}{c}\mathrm{Ba} \\
\text { haya }\end{array}$ \\
\hline Sidorejo & $\begin{array}{c}\mathrm{A} \\
\mathrm{man}\end{array}$ & $\begin{array}{c}\mathrm{A} \\
\text { man }\end{array}$ & $\begin{array}{c}\mathrm{A} \\
\text { man }\end{array}$ & $\begin{array}{c}\mathrm{Ba} \\
\text { haya }\end{array}$ & $\begin{array}{c}\mathrm{A} \\
\text { man }\end{array}$ & $\begin{array}{c}\mathrm{A} \\
\text { man }\end{array}$ & $\begin{array}{c}\text { Ba } \\
\text { haya }\end{array}$ \\
\hline Panggungrejo & $\begin{array}{c}\mathrm{A} \\
\mathrm{man}\end{array}$ & $\begin{array}{c}\mathrm{A} \\
\text { man }\end{array}$ & $\begin{array}{c}\mathrm{A} \\
\text { man }\end{array}$ & $\begin{array}{c}\text { Ba } \\
\text { haya }\end{array}$ & $\begin{array}{c}\mathrm{A} \\
\text { man }\end{array}$ & $\begin{array}{c}\mathrm{A} \\
\text { man }\end{array}$ & $\begin{array}{c}\mathrm{A} \\
\text { man }\end{array}$ \\
\hline
\end{tabular}

\section{KESIMPULAN}

Sistem pendukung keputusan penilaian pencemaran udara di PG Mojopanggung Tulungagung dengan metode weighted product menggunakan dua penilaian yaitu limbah gas cerobong ketel dan kualitas udara ambien desa di sekitar PG Mojopanggung. Dengan penilaian limbah gas cerobong ketel dapat diketahui cerobong ketel mana yang menghasilkan limbah paling banyak, sedangkan dengan penilaian kualitas udara ambien desa di sekitar PG Mojopanggung dapat diketahui desa mana yang paling terdampak dari limbah gas PG Mojopanggung.

Hasil penelitian menunjukkan bahwa dari sisi limbah gas, Cerobong Boiler Stork I merupakan cerobong yang paling banyak mengeluarkan limbah gas, sedangkan nilai pencemaran oleh cerobong ketel di Pabrik Gula Mojopanggung semuanya tidak melebihi baku mutu yang telah ditentukan. Sebaliknya dari sisi kualitas udara ambien, desa Jatimulyo merupakan desa yang paling terdampak oleh limbah gas dari Pabrik Gula Mojopanggung. Ada beberapa polutan udara yang melebihi baku mutu yang telah ditentukan namun tidak terlalu banyak selisihnya. Untuk mengatasi polutan udara yang melebihi baku mutu tersebut maka Pabrik Gula Mojopanggung melakukan pengolahan limbah gas dan beberapa solusi lainnya". 


\section{DAFTAR PUSTAKA}

[1] A. Chusnaini, "Masa Kejayaan Industri Gula Indonesia," 26 October 2017. [Online]. Available: ptpn11.co.id/berita/masa-kejayaan-industrigulaindonesia. [Accessed 6 November 2017].

[2] Hafiyyan, "Manis dengan Pabrik Gula Baru," 24 January 2017. [Online]. Available:

kalimantan.bisnis.com/read/20170124/442/622121/manisdenganpabrik-gula-baru. [Accessed 6 November 2017].

[3] A. Rudystina, "Dampak Polusi Udara terhadap Kesehatan," 5 September 2017. [Online]. Available: hellosehat.com/hidupsehat/tipssehat/dampak-polusi-udara-terhadap-kesehatan. [Accessed 26 October 2017].

[4] Pemerintah Provinsi Jawa Timur, Peraturan Gubernur Jawa Timur No. 10 Tahun 2009 Tentang Baku Mutu Udara Ambien dan Emisi Sumber Tidak Bergerak Di Jawa Timur, Surabaya: Pemerintah Provinsi Jawa Timur, 2019.

[5] D. Nofriansyah, Konsep Data Mining VS Sistem, Yogyakarta: Deep Publish, 2014

[6] D. M. Khairina, D. Ivando and S. Maharani, "Implementasi Metode Weighted Product Untuk Aplikasi Pemilihan Smartphone Android," Jurnal Infotel, vol. 8, no. 1, 2016.

[7] N. A. Syafitri, Sutardi and A. P. Dewi, "Penerapan Metode Weighted Product Dalam Sistem Pendukung Keputusan Pemilihan Laptop Berbasis Web," Jurnal SemanTIK, vol. 2, no. 1, 2016.
[8] A. Rosyidah, "Pemberdayaan Petani Tebu sebagi Upaya Pabrik Gula dalam Meningkatkan Perekonomian Daerah," 24 June 2015. [Online]. Available: www.kompasiana.com/aiukolor/pemberdayaan-petanitebusebagai-upaya-pabrik-gula-dalam-meningkatkanekonomidaerah_5520d7bfa33311704946ce27. [Accessed 7 November 2017].

[9] U. Hasanah, "Analisis Pengendalian Kualitas Gula Pada PG Mojo Di Kabupaten Sragen Dengan Metode Six Sigma - DMAIC," Program Studi Teknik Industri Fakultas Sains dan Teknologi Universitas Islam Negeri, Yogyakarta, 2013.

[10] F. S. Putri, "Eksistensi Limbah Pabrik Gula Di Tengah Masyarakat Kelurahan Banjarejo Kecamatan Taman Kota Madiun Perspektfi Hukum Islam," Program Studi Hukum Bisnis Syariah Fakultas Syariah Universitas Islam Negeri Maulana Malik Ibrahim, Malang, 2016.

[11] L. M. Arief, Pengolahan Limbah Industri, Jakarta: Fakultas Kesehatan Masyarakat Universitas Esa Tunggul, 2013.

[12] B. Setiawan, "Pengkelompokan Limbah Berdasarkan," 31 December 2014. [Online]. Available: ilmulingkungan.com/pengelompokanlimbah-berdasarkanbentuk-atau-wujudnya. [Accessed 8 November 2017]. 